\title{
Pedological Characterization and Classification of Selected Soils of Morogoro and Mbeya Regions of Tanzania
}

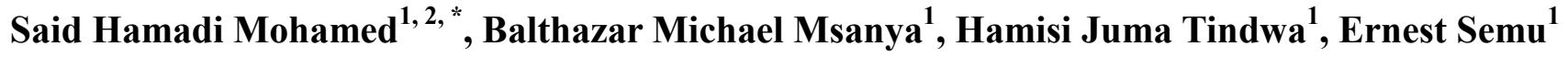 \\ ${ }^{1}$ Department of Soil and Geological Sciences, Sokoine University of Agriculture, Morogoro, Tanzania \\ ${ }^{2}$ Department of Molecular Biology and Biotechnology, University of Dar es Salaam, Dar es Salaam, Tanzania

\section{Email address:} \\ gsapze@gmail.com (S. H. Mohamed),bmmsanya@gmail.com (B. M. Msanya), hamisitindwa@gmail.com (H. J. Tindwa), \\ semu@suanet.ac.tz (E. Semu) \\ ${ }^{*}$ Corresponding author
}

\section{To cite this article:}

Said Hamadi Mohamed, Balthazar Michael Msanya, Hamisi Juma Tindwa, Ernest Semu. Pedological Characterization and Classification of Selected Soils of Morogoro and Mbeya Regions of Tanzania. International Journal of Natural Resource Ecology and Management. Vol. 6, No. 2, 2021, pp. 79-92. doi: 10.11648/j.ijnrem.20210602.17

Received: May 30, 2021; Accepted: June 10, 2021; Published: June 16, 2021

\begin{abstract}
This study was done in Morogoro and Mbeya regions of Tanzania to classify and characterize their respective soils. Representative pedons (SUARAT-P1 and UYOLE-P1) were dug and described using FAO guidelines clarifying morphological features, physico-chemical properties and genesis. The representative pedons were geo-referenced using Global Positioning System (GPS) receiver. A total of nine (9) genetic soil horizons were identified from both sites and samples from each horizon collected for physical and chemical analyses. Soils from both sites were very deep and topsoil moist colors ranged from hue of 7.5YR to 10YR with chroma of less than 3 in SUARAT-P1 and UYOLE-P1 pedons. Soil structure ranged from strong fine crumbs in topsoils to medium coarse sub-angular blocks in subsoils of SUARAT-P1 while UYOLE-P1 had weak fine sub-angular blocks in topsoils and subsoils. The SUARAT-P1 had sandy clay (SC) texture in topsoil and clay texture in subsoil while UYOLE-P1 had sandy loam (SL) in topsoil and sand clay loam (SCL) in subsoil. Soil reaction were slightly acid to very strongly acid in SUARAT-P1 ( $\mathrm{pH} 6.54$ - 4.46) whereas UYOLE-P1 were slightly acid to neutral in subsoil horizons (pH 6.35 7.32). Organic carbon ranged from very low to low (0.12- 0.95\%) in SUARAT-P1 and from very low to medium $(0.47-1.5 \%)$ in UYOLE-P1. Nitrogen levels were very low to low $(0.05-0.12 \%)$ in both sites whereas available P ranged from low $\left(0.30 \mathrm{mg} \mathrm{kg}^{-1}\right)$ to medium ( $\left.8.55 \mathrm{mg} \mathrm{kg}^{-1}\right)$ in both pedons. CEC of SUARAT-P1 was medium ranging from 12.4 to $23.2 \mathrm{cmol}(\mathrm{c}) \mathrm{kg}^{-1}$, whereas UYOLE-P1 was medium to high $\left(15-34 \mathrm{cmol}(\mathrm{c}) \mathrm{kg}^{-1}\right)$. In SUARAT-P1, topsoil BS was high $(>50 \%)$ and low $(<50 \%)$ in the subsoil while UYOLE-P1 registered high BS throughout its profile depth. As diagnostic horizons for soil classification, the SUARAT-P1 had an ochric epipedon overlying a kandic horizon and classified according to USDA Soil Taxonomy as Typic Kandiustults, while UYOLE-P1 had an ochric epipedon over a cambic horizon and was named as Andic Dystrudepts corresponding respectively to Haplic Lixisols and Eutric Andic Cambisols in the WRB for Soil Resources. The results have indicated that, studied soils are less fertile with possible reconstitution through land and crop managements which include but not limited to no-tilling or conservation tillage, manuring and proper fertilizer application; residue retention, possible fallowing, liming for potential buffering of soil $\mathrm{pH}$ especially at SUARAT-P1 and crop rotation and intercropping with leguminous crops.
\end{abstract}

Keywords: Pedological Characterization, Soil Morphological Characteristics, Physico-chemical Properties, Soil Classification, Tanzania

\section{Introduction}

Soils are characteristically differing in their level of fertility and other related chemical and physical aspects depending on locality and their natural evolution [1]. For example soils originating from volcanic ash materials have high anion retention capacity and humus-rich horizons [2].

Kalala et al. [3] reported other soils in Kilombero Valley which developed from alluvial materials deposited by floods during rainy seasons behaving differently.

Soil Taxonomy (ST) defines soil as "a natural body that is formed by solid particles (minerals and organic matter), 
natural gases and liquid materials that occur on the land surface, occupying space, and is portrayed by one or both of the following: layers and, or horizons, that are distinguishable from the initial material as a result of additions, losses, transfers, and transformations of energy and matter or the ability to support rooted plants in a natural environment [4]. Formation of soils is essentially contributed by several important factors: the native parent materials, climate, topography, biological components and time [3]. Their influence on soil types varies accordingly from one location to another and depends on accumulated individual interaction of each factor [5].

Composition of solum which is the upper part of soil and subsolum and underground parent material are used to give general, site specific recommendations on soil fertility status, potential soil limitations and provides information on agro-ecologically supported crops [3]. Therefore, information accruing from pedological characterization and classification of soils is of prime importance for agriculture activities [6]. Furthermore, systematic identification, grouping and delineation of various soil types is very important in interpretation, decision making on land use and management types on different crops and conservation activities [7, 8]. According to daily land uses, it is recommended that frequent observation of soils on different aspects of chemical and physical characteristics is important for current recommendations on sustainable crop production [9]. the Annual Agricultural Sample Survey (AASS) report of Tanzania of the year 2016/2017 [10], Mbeya and Morogoro Regions among other regions have had the highest production of maize and rice, having crop yields of $3.7 \mathrm{Mg} \mathrm{ha}^{-1}$ of maize and $4 \mathrm{Mg}$ ha- 1 of rice. Despite use of inorganic fertilizers, it is important to note that there is a serious problem of soil fertility due to intensive farming and different soil management systems leading to different nutrient deficiency levels.

Characterization and classification of the soils of the two regions was the aim of this study to generate important information on the morphological, physical and chemical properties of the soils thereby permitting their classification according to the United States Department of Agriculture (USDA) Soil Taxonomy [11] and the FAO World Reference Base (WRB) for Soil Resources [12]. The specific site soil information is essential for future decision making on the diversified soil management to enhance sustenance of agricultural production.

\section{Materials and Methods}

\subsection{Description of the Study Areas}

The study was conducted at Uyole and Magadu respectively in Mbeya and Morogoro Regions of Tanzania. Mbeya Region is located in Southwest Tanzania and lies between latitude $6^{\circ}$ $52^{\prime} 00^{\prime \prime S}$ and $9^{\circ} 41^{\prime} 00^{\prime \prime} \mathrm{S}$ and longitude $32^{\circ} 01^{\prime} 00^{\prime \prime} \mathrm{E}$ and $35^{\circ}$ $01^{\prime} 00^{\prime \prime} \mathrm{E}$, with an altitude ranging from $1700 \mathrm{~m}$ to $2960 \mathrm{~m}$ above mean sea level. The study site in Mbeya Region is Uyole Agricultural Research Station which is located at latitude $08^{\circ} 54^{\prime} 58.1^{\prime \prime} \mathrm{S}$ and longitude $033^{\circ} 30^{\prime} 54.3^{\prime \prime} \mathrm{E}$ with an altitude of $1779 \mathrm{~m}$ above mean sea level. The site neighbors the volcanic Mbeya Mountains.

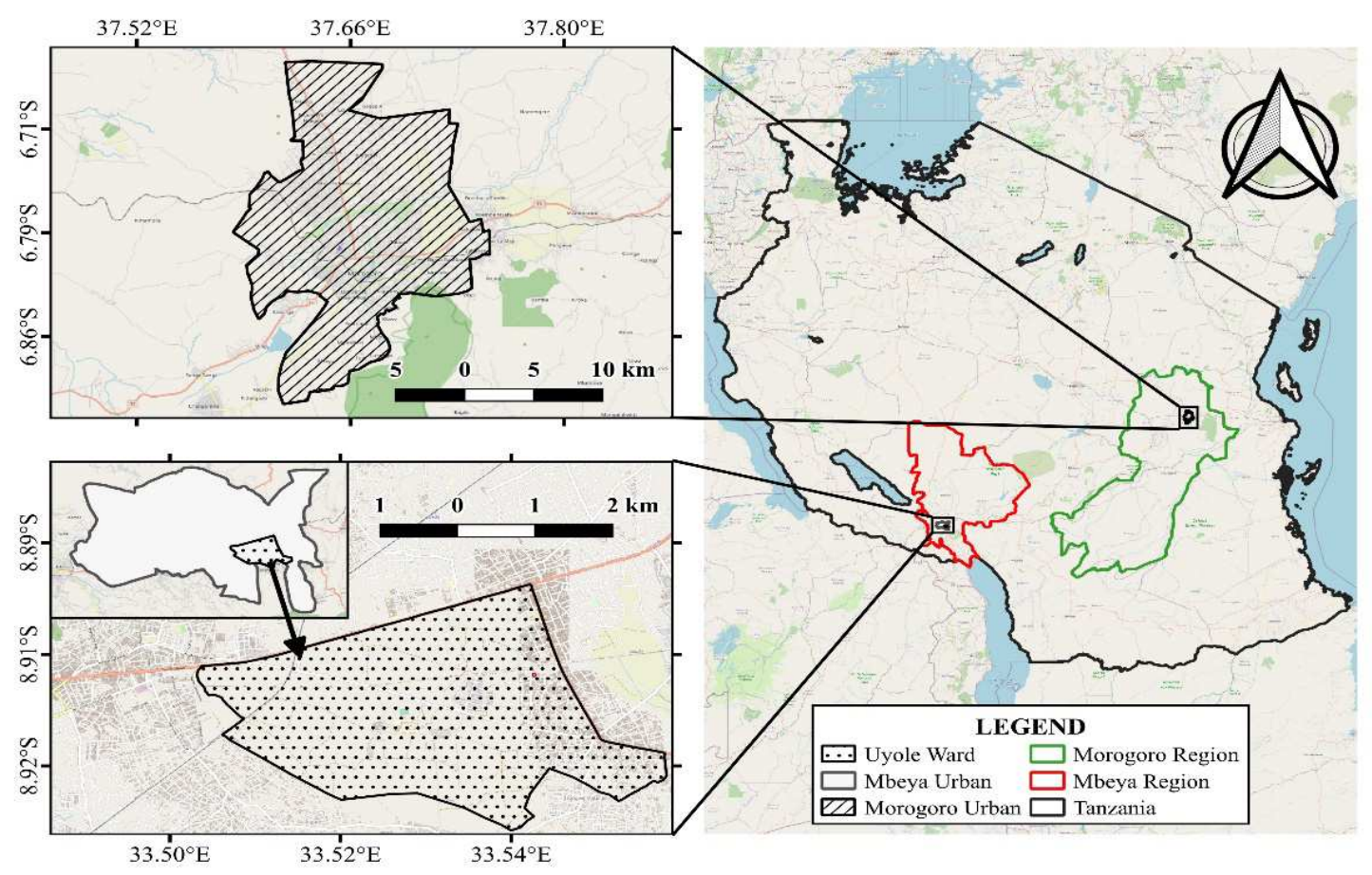

Figure 1. A map showing location of Mbeya and Morogoro Regions.

Morogoro Region on the other hand lies east of Dodoma City) (Tanzania's capital city) and west of Coast and Dar es Salaam Regions. In terms of geographical coordinates, the region lies between latitudes $5^{\circ} 48^{\prime} 00^{\prime \prime} \mathrm{S}$ and $9^{\circ} 57^{\prime} 00^{\prime \prime} \mathrm{S}$ and between longitudes $35^{\circ} 17^{\prime} 00^{\prime \prime} \mathrm{E}$ and $38^{\circ} 30^{\prime} 00^{\prime \prime} \mathrm{E}$. The study site in Morogoro Region (Magadu, Sokoine University of Agriculture) is 
located at latitude $06^{\circ} 51^{\prime} 07.1^{\prime \prime} \mathrm{S}$ and longitude $037^{\circ} 38^{\prime} 28.9^{\prime \prime} \mathrm{E}$.

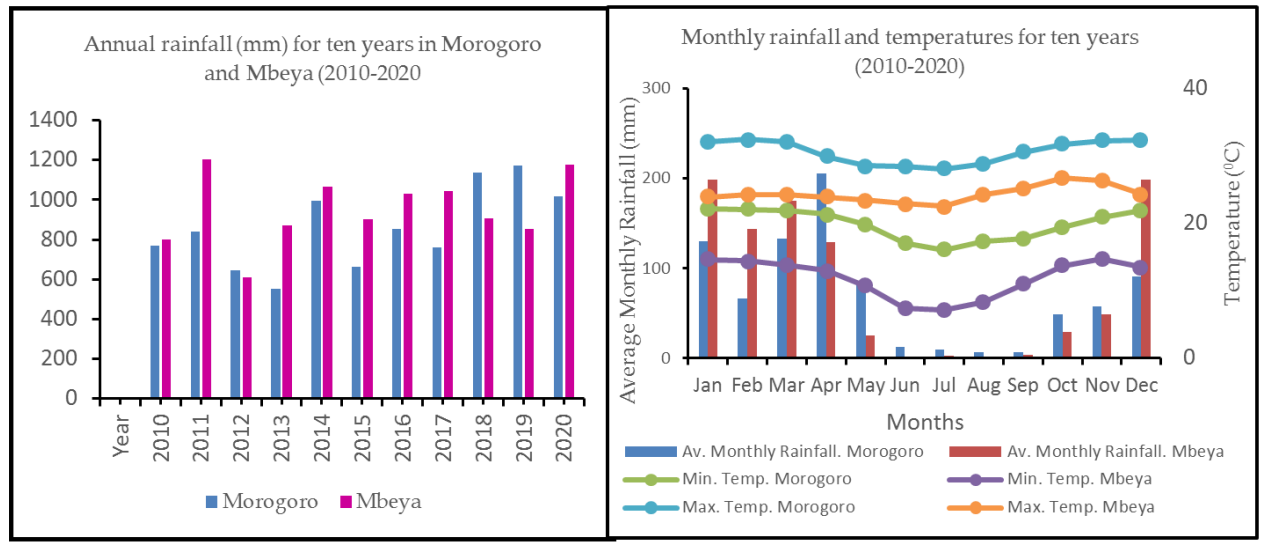

Figure 2. Annual and monthly rainfall, maximum and minimum temperature of Morogoro and Mbeya (Uyole).

Table 1. Site Characteristics of the studied pedons at Magadu and Uyole sites, Tanzania.

\begin{tabular}{|c|c|c|}
\hline \multirow{2}{*}{ Attributes } & \multicolumn{2}{|l|}{ Description } \\
\hline & Magadu (SUARAT- P1) & Uyole (UYOLE P1) \\
\hline Coordinates & $037^{\circ} 38^{\prime} 28.9^{\prime \prime} \mathrm{E}, 6^{\circ} 51^{\prime} 07.1^{\prime \prime} \mathrm{S}$ & $033^{\circ} 30^{\prime} 54.3^{\prime \prime} \mathrm{E}, 08^{\circ} 54^{\prime} 58.1^{\prime \prime} \mathrm{S}$ \\
\hline Altitude (m.a.s.l) & 541 & 1779 \\
\hline Landform & Plain; linear/straight & Flat or almost flat land \\
\hline Parent material / Lithology & $\begin{array}{l}\text { Colluvio-alluvium derived from the Uluguru Mountains consisting mainly of } \\
\text { hornblende-pyroxene granulites, with plagioclase and quartz rich veins }\end{array}$ & $\begin{array}{l}\text { Colluvio-alluvium derived from the } \\
\text { Mbeya Volcanic Mountains }\end{array}$ \\
\hline Slope $\%$ & 4 & 2 \\
\hline Land use / Vegetation & $\begin{array}{l}\text { Agriculture (maize, soybean, rice, cowpea and mixed crops) Research for rat } \\
\text { mine detection }\end{array}$ & $\begin{array}{l}\text { Agriculture (maize, soybean, beans, } \\
\text { wheat, Irish potatoes) }\end{array}$ \\
\hline Mean annual rainfall (mm) & $600-1000 \mathrm{~mm}$ & $1200-1730 \mathrm{~mm}$ \\
\hline SMR & Ustic & Udic \\
\hline \multicolumn{3}{|l|}{ Mean annual temperature ${ }^{\circ} \mathrm{C}$} \\
\hline STR & Isohyperthermic & Thermic \\
\hline
\end{tabular}

KEY: SMR= Soil moisture regime; $\mathrm{STR}=$ Soil temperature regime; m.a.s.l $=$ above mean sea level

\subsection{Climate}

Morogoro Region has a tropical savanna climate experiencing a bimodal rainfall distribution pattern with two rainfall peaks per year, defining the short rain season starting from October through December and the long rain season from March to May. At higher altitudes around Uluguru Mountains the rainfall is approaching $1000 \mathrm{~mm}_{\text {year }}{ }^{-1}$ while at low altitude plains rainfall as low as $600 \mathrm{~mm}_{\text {year }}{ }^{-1}$ is recorded [13]. Monthly mean maximum and minimum temperature recorded are respectively $30.1^{\circ} \mathrm{C}$ and $19.6^{\circ} \mathrm{C}$ [14].

Mbeya Region has a subtropical highland climate with a monomodal rainfall distribution pattern. The onset of the rains starts in late November and ends in early May with dry spells in between. The average annual minimum and maximum temperatures are 12.6 and $24.7^{\circ} \mathrm{C}$ respectively, with coldest temperatures recorded in the months of June and July reaching up to $7^{\circ} \mathrm{C}[14]$.

\subsection{Field Methods}

Reconnaissance survey was done at Uyole Agricultural Research Station and Magadu (SUA) using transect walks and soil augering, sampling and descriptions to identify sampling areas. At each observation point, site data on landform, soil morphological features (soil color, texture, consistence, structure, porosity, and effective depth), parent material, natural vegetation, drainage, slope gradient, elevation, erosion and land use were recorded and filled in forms designed by the National Soil Service, Tanzania, adopted from the FAO Guidelines for Soil Description [15]. Soil color was determined using Munsell Color Charts [16]. Soil pits of $2.5 \mathrm{~m}$ length, $1.5 \mathrm{~m}$ width and $2 \mathrm{~m}$ depth were excavated in the representative sites. The locations of the study sites were recorded using Global Positioning System (GPS) model GARMIN (etrex 20). Disturbed (bulk) and undisturbed (core) soil samples were taken from each identified horizon from each site for physical and chemical analysis in the laboratory.

\subsection{Laboratory Methods}

The disturbed soil samples were air dried for 2-3 days, mixed well and after gentle crushing were passed through a 2 mm sieve. The soil $\mathrm{pH}_{\mathrm{H} 2 \mathrm{O}}$ and $\mathrm{pH}_{\mathrm{KCl}}$ were potentiometrically measured by using $\mathrm{pH}$ meter in a 1:2.5 soil:water and soil: $1 \mathrm{~N}$ $\mathrm{KCl}$ ratios [17], respectively. Organic carbon (OC) of soil samples was determined by the wet oxidation method of Walkley-Black [18] and corresponding soil organic matter (SOM) was calculated by multiplying OC by a factor of 1.724 [18]. Total nitrogen was determined by macro-Kjeldahl digestion distillation method [19, 20]. 
Bulk density (BD) of undisturbed soil samples was determined by weighing soil cores after overnight drying at $105^{\circ} \mathrm{C}$ [17]. Available phosphorus was extracted using the method of Bray and Kurtz [21, 22] and determined by spectrophotometer at $884 \mathrm{~nm}$ wavelength following color developed by the molybdenum blue method [23, 17]. Particle size analysis was determined by hydrometer method after dispersion with 5\% sodium hexametaphosphate [24, 20]. Soil textural classes were determined using the USDA textural class triangle [15]. Micronutrients ( $\mathrm{Cu}, \mathrm{Fe}, \mathrm{Zn}$, and $\mathrm{Mn}$ ) were extracted by diethylenetriaminepentaacetic acid (DTPA) method and determined using atomic absorption spectrophotometer [25]. Cation exchange capacity of soil (CECsoil) was determined by saturating soil with neutral $1 \mathrm{M}$ NH4OAc (ammonium acetate) and the adsorbed NH4+ were displaced by using $1 \mathrm{M} \mathrm{KCl}$ and then determined by Kjeldahl distillation method for estimation of CEC of soil [26]. The exchangeable bases $\left(\mathrm{Ca}^{2+}, \mathrm{Mg}^{2+}, \mathrm{Na}^{+}, \mathrm{K}^{+}, \mathrm{Al}^{+3}\right.$ and $\left.{ }^{\mathrm{H}+}\right)$ were determined by atomic absorption spectrophotometer (AAS) [27]. Total exchangeable bases (TEB) were calculated as sum of exchangeable bases $\mathrm{Ca}^{2+}, \mathrm{Mg}^{2+}, \mathrm{Na}^{+}$and ${ }^{\mathrm{K}+}$. Exchangeable $\mathrm{Al}^{3+}$ and $\mathrm{H}^{+}$were used to predict total exchangeable acidity (TEA). Percent base saturation (PBS) was calculated by dividing the sum of the basic cations $\left(\mathrm{Ca}^{2+}, \mathrm{Mg}^{2+}, \mathrm{Na}^{+}, \mathrm{K}^{+}\right)$by the CEC of the soil and multiplying by 100 . Cation exchange capacity of clay (CECclay) was determined by the formula of Baize [28] which corrects for the CEC contributed by organic matter as follows:

$$
\text { CECclay }=(\{\text { CECsoil }-(\% \text { OM } \times 2)\} / \% \text { clay } \times 100
$$

Electrical conductivity (EC) was determined in a 1:2.5 soil: water suspension using an electrical conductivity meter as described by [20].

Soil penetration resistance (PR) in each soil horizon was measured using pocket cone penetrometer (Daiki Rika Kogyo penetrometer Model DIK-5551) [29]. PR of soil is a measure of its strength to resist penetration, compactness or cohesiveness. The cone penetrometer is made up of a replaceable stainless steel cone structure of a tip of $30^{\circ}$ angle and a rod base of $12.82 \mathrm{~mm}$ diameter [29, 30]. The soil penetrability is measured as Cone Index (CI) and is expressed as force per unit cross-sectional area of the cone base [29]. The measurements of penetration resistance (PR) were taken five times from each horizon. The mean penetrometer readings for each horizon in millimeter $(\mathrm{mm})$ were converted to megaPascals (MPa) according to Massawe et al. [31]. The penetration resistance was then calculated as follows:

$$
\text { Penetration resistance }\left(\mathrm{kg} \mathrm{cm}^{-2}\right)=(100 * \mathrm{X}) / 0.7952(40-\mathrm{X})^{2}
$$

Where, $\mathrm{X}=$ penetrometer readings $(\mathrm{mm})$ and $1 \mathrm{~kg} \mathrm{~cm}^{-2}=$ $0.09807 \mathrm{MPa}$

Total elemental composition of three selected horizons of the representative soil profiles was determined as follows [3]: using a swing mill pulverizer, soil samples were ground to the particle size of $\leq 177 \mu \mathrm{m}$ diameter and then pressed into XRF cups and mounted with PANalytical B. V. X-Ray film-polyester PETP (Polyethylene Terephthalate Polyester). The elemental oxides were then measured by PANalytical, Minipal 4 Energy Dispersive X-Ray Fluorescence Spectrophotometer (ED-XRF) (Model PW4030/45B USA).

\subsection{Soil Classification}

The collected field data (site characteristics, climate and soil morphological features) and data obtained from laboratory analyses (physical and chemical properties of the soils) were used to classify the soils to family level of the USDA Soil Taxonomy [11] and to tier-2 of the FAO World Reference Base for Soil Resources [12].

\section{Results and Discussion}

\subsection{Soil Morphological Characteristics}

The morphological characteristics of studied pedons are showed in Table 2 . Both pedons are very deep $(>150 \mathrm{~cm})$, with natural drainage classified as well to excessively well drained and well drained in Magadu and Uyole respectively. Pedon SUARAT-P1 had sandy clay topsoil overlying a thick clayey subsoil extending to a depth of $>180 \mathrm{~cm}$. Pedon UYOLE-P1 had a coarser texture characterized by a sandy loam topsoil overlying sand clay loam to sandy loam/loamy sand subsoil. The topsoil color of pedon SUARAT-P1 ranged from dark brown to brown overlying dark red brown and yellowish red subsoil color. On the other hand pedon UYOLE-P1 had intense black topsoil color typical of volcanic materials and/or organic matter deposition overlying a subsoil with varied brown colors [32].

Both SUARAT-P1 and UYOLE-P1 pedons had almost comparable consistence rated from very friable to friable consistence indicating good water movement and root penetration [33]. According to Peverill et al. [33], soil consistence is generally used as a measure of soil permeability and root penetration; loose and soft (friable) consistence imply easy water movement but harder and more rigid consistence would imply less water movement and poorer root penetration.

The structure of pedon SUARAT-P1 was rated as strong fine crumby in the topsoil overlying moderate to weak coarse and medium subangular blocky subsoil. Pedon UYOLE-P1 had weak fine and medium subangular blocky structure in the topsoil overlying a subsoil with varying structures ranging from weak fine and very fine subangular blocky to structureless single-grained. Crumby and subangular blocky structures correlate with good aeration, root penetration and drainage [34]. In both studied pedons the structures identified suggest good aeration, easy root penetration and smooth water movements.

Clay cutans were observed in the subsoil of pedon SUARAT-P1 indicating that the processes of eluviation and illuviation have been active pedogenic processes in this pedon [6].

Horizon boundaries in topsoils of both pedons were clear wavy, while subsoils of pedon SUARAT-P1 were diffuse smooth and those of pedon UYOLE-P1 abrupt wavy. 


\subsection{Soil Physical Characteristics}

Results of soil physical properties are presented in Table 3.

\subsubsection{Soil Particle Distribution (Texture), Silt/Clay Ratio and Bulk Density (BD)}

Soil particle distribution is the relationship that shows different percentages of gravel, sand, silt and clay particles of certain soil [30]. Soil texture is one of the most stable and significant soil physical properties which have influence on other soil attributes including erodibility, water holding capacity, infiltration rate, nutrient retention, workability, soil consistence, soil aeration and fertility $[35,6]$.

The clay content of the SUARAT-P1 pedon distinctly increased with depth from $35.8 \%$ in topsoil to $68.8 \%$ in subsoil through the process of eluviation-illuviation as indicated by the presence of clay cutans in the subsoil (Table 2). On the other hand, sand content gradually decreased down the profile from $58.24 \%$ in topsoil to $28.24 \%$ in subsoil. The fineness of the texture in this pedon might suggest that the soil has high water retention and nutrient supply capacity. In the case of UYOLE-P1 pedon, the particle size distribution was quite different where by, the soil texture was generally coarser and showed no clear trend of change with depth. The highest clay content recorded was $28.8 \%$ in the $\mathrm{B}$ horizon while the least recorded was $8.8 \%$ in the $\mathrm{C}$ horizon. There was dominance of sand fraction in all horizons, where the content ranged from $56.24 \%$ in topsoil and decreased to $48.24 \%$ in the B horizon and thereafter increased dramatically to $82.24 \%$ in the $\mathrm{C}$ horizon. The coarseness of the texture suggests that the soil has low water retention, poor physical stability and generally low fertility $[36,35]$.

The silt/clay ratio of a given soil shows the extent of soil aging [37]. According to Ribeiro [38], silt to clay ratio of greater than 0.12 is an indication of less weathered and younger parent materials [39]. The silt/clay ratios of the two studied soils are relatively higher in topsoils than in subsoils indicating that subsoils are more weathered than topsoils. The subsoil of pedon SUARAT-P1 had silt/clay ratio much smaller than 0.12 implying that this pedon is highly weathered. In the case of pedon UYOLE-P1, all horizons had silt/clay ratios greater than 0.12 indicating that the pedon is genetically young in terms of weathering and development $[2,3]$.

Bulk density (BD) is a physical property of a soil that indicates compactness of soil particles, and their values indicate how well the aeration and root penetration are [40]. Increase in $\mathrm{BD}$ values indicates reduction of water infiltration rate and consequently an increase in runoff [40]. Bulk density of both studied sites are $<1.6 \mathrm{~g} \mathrm{~cm}^{-3}$ in all studied horizons which according to Landon [40] and Arshad et al. [41] do not pose any limitation to root growth, aeration and water movement.

Table 2. Selected morphological features of soil pedons of Magadu and Uyole Sites, Tanzania.

\begin{tabular}{|c|c|c|c|c|c|c|c|c|c|c|c|}
\hline Profile & Horizon & $\begin{array}{l}\text { Depth } \\
\text { (cm) }\end{array}$ & Texture & $\begin{array}{l}\text { Moist } \\
\text { Colour }\end{array}$ & Consistence $^{2}$ & Structure $^{3}$ & Pores $^{4}$ & $\begin{array}{l}\text { Rock } \\
\text { fragment }^{5}\end{array}$ & Roots $^{6}$ & Cutans $^{7}$ & $\begin{array}{l}\text { Horizon } \\
\text { Boundary }^{8} \\
\end{array}$ \\
\hline \multirow[t]{4}{*}{ SUARAT-P1 } & $\mathrm{Ah}$ & $0-5 / 8$ & $\mathrm{SC}$ & $\begin{array}{l}\mathrm{db} \\
(7.5 \mathrm{YR} 3 / 2)\end{array}$ & vfr, ss \& p & sf \& m, cr & $\mathrm{mc} \& \mathrm{~mm}$ & - & $\mathrm{cf}, \mathrm{mm} \& \mathrm{fc}$ & - & $\mathrm{cW}$ \\
\hline & $\mathrm{BA}$ & $5 / 8-23$ & $\mathrm{SC}$ & b (7.5YR4/4) & fr, s \& p & $\mathrm{mc} \& \mathrm{~m}, \mathrm{sbk}$ & $\begin{array}{l}\mathrm{cc}, \mathrm{mm}, \mathrm{mf} \\
\& \mathrm{mvf}\end{array}$ & - & $\mathrm{cf} \& \mathrm{fc}$ & $\mathrm{ffc}$ & ds \\
\hline & Bt1 & $23-42$ & $\mathrm{C}$ & $\operatorname{drb}(5 \mathrm{YR} 3 / 4)$ & fr, s \& p & w-mc, sbk & $\begin{array}{l}\mathrm{fm}, \mathrm{mf} \& \\
\mathrm{mvf}\end{array}$ & - & $\mathrm{fm}, \mathrm{cc} \& \mathrm{cf}$ & $\mathrm{ffc}$ & ds \\
\hline & $\mathrm{Bt} 3$ & $88-185+$ & $\mathrm{C}$ & yr (5YR5/8) & fr, s \& p & sm, sbk & $\begin{array}{l}\mathrm{mf}, \mathrm{mvf}, \mathrm{cm} \\
\& \mathrm{vfc}\end{array}$ & - & $\mathrm{fm} \& \mathrm{cf}$ & fdc & - \\
\hline \multirow[t]{3}{*}{ UYOLE-P1 } & Ap & $0-19 / 25$ & SL & bl (10YR2/1) & fr, ss \& sp & wf \& m, sbk & $\begin{array}{l}\mathrm{cm}, \mathrm{mf} \& \\
\mathrm{mvf}\end{array}$ & $\mathrm{cm}$, fa-p & $\mathrm{mf}$ & - & $\mathrm{cw}$ \\
\hline & Bw1 & $\begin{array}{l}19 / 25- \\
60 / 86\end{array}$ & SCL & $\mathrm{db}(10 \mathrm{YR} 3 / 3)$ & fr, s \& p & wf \& vf, sbk & $\begin{array}{l}\mathrm{cm}, \mathrm{mf} \& \\
\mathrm{mvf}\end{array}$ & fm, fsa-p & $\mathrm{cf}$ & - & aw \\
\hline & $\mathrm{Ab} / \mathrm{Bw} 2 \mathrm{~b}$ & $\begin{array}{l}125 / 131- \\
210+\end{array}$ & SL & $\mathrm{db}(10 \mathrm{YR} 3 / 3)$ & fr, s \& p & w \& mc, sbk & $\begin{array}{l}\mathrm{cm} \& \mathrm{cc}, \mathrm{cf} \\
\& \mathrm{cvf}\end{array}$ & - & fvf & - & - \\
\hline
\end{tabular}

KEY:

${ }^{1}$ Moist color: $\mathrm{db}=$ dark brown; $\mathrm{b}=$ brown; $\mathrm{yb}=$ yellowish brown; $\mathrm{yr}=$ yellowish red; $\mathrm{drb}=$ dark reddish brown; $\mathrm{bl}=\mathrm{black}$; lob= light olive brown; $\mathrm{vdgb}=\mathrm{very}$ dark greyish brown; dyb = dark yellowish brown; $\mathrm{vdb}=$ very dark brown

${ }^{2}$ Consistence: $v f r=$ very friable; $f r=$ friable; $s=$ sticky; $s s=$ slightly sticky; $s p=$ slightly plastic; $s s-s=$ slightly sticky to sticky; $s p-p=$ slightly plastic to plastic

${ }^{3}$ Structure: $\mathrm{mf}=$ moderate fine; $\mathrm{sbk}=$ subangular blocky; $\mathrm{wf}=$ weak fine; $\mathrm{vf}=$ very fine; $\mathrm{m}=$ medium; $\mathrm{sf}=\mathrm{strong}$ fine; $\mathrm{cr}=\mathrm{crumby} ; \mathrm{c}=\mathrm{coarse} ; \mathrm{mc}=\mathrm{moderate}$ coarse; $\mathrm{w}=$ weak; $\mathrm{sm}=$ strong medium; $\mathrm{sl}-\mathrm{sgr}=$ structureless single grained; $\mathrm{fc}=$ few coarse; $\mathrm{pmc}=$ pumice; ands $=$ andesite

${ }^{4}$ Pores: $\mathrm{mm}=$ many medium; $\mathrm{fm}=$ few medium $; \mathrm{mc}=$ many coarse $; \mathrm{fc}=$ few coarse; $\mathrm{vfc}=$ very few coarse $; \mathrm{mf}=\mathrm{many}$ fine; $\mathrm{mvf}=\mathrm{many}$ very fine; $\mathrm{cvf}=\mathrm{common}$ very fine; $\mathrm{cc}=$ common coarse; $\mathrm{cm}=$ common medium; $\mathrm{cf}=$ common fine;

${ }^{5}$ Rock fragments: $\mathrm{cm}=$ common medium; $\mathrm{fm}=$ few medium; $\mathrm{vf}=$ very few; fa- $\mathrm{p}=$ friable angular pumices; fsa- $\mathrm{p}=$ friable subangular pumices; $1 \mathrm{~s}-\mathrm{p}=\mathrm{loose}$ pumices

${ }^{6}$ Roots: $\mathrm{cf}=$ common fine; $\mathrm{ff}=$ few fine; $\mathrm{mf}=$ many fine; $\mathrm{vff}=$ very few fine; $\mathrm{mm}=$ many medium; $\mathrm{cc}=\mathrm{common}$ coarse; $\mathrm{fc}=\mathrm{few}$ coarse; fm $=$ few medium; $\mathrm{cvf}$ $=$ common very fine; $f v f=$ few very fine

${ }^{7}$ Cutans: ffc $=$ few faint clay cutans; fdc $=$ few distinct clay cutans

${ }^{8}$ Horizon boundary: $\mathrm{cw}=$ clear wavy; $\mathrm{ds}=$ diffuse smooth; aw = abrupt wavy 
Table 3. Some physical properties of studied areas of Magadu and Uyole Sites, Tanzania.

\begin{tabular}{|c|c|c|c|c|c|c|c|c|c|c|}
\hline Profile & Horizon & Depth (cm) & Sand & Silt & Clay & $\begin{array}{l}\text { Textural } \\
\text { Class } \\
\end{array}$ & $\begin{array}{l}\text { Silt/Clay } \\
\text { ratio }\end{array}$ & $\begin{array}{l}\text { BD } \\
\text { g/ce }\end{array}$ & Porosity\% & $\begin{array}{l}\text { Penetration } \\
\text { resistance (MPa) }\end{array}$ \\
\hline \multirow{5}{*}{ SUARAT-P1 } & $\mathrm{Ah}$ & $0-5 / 8$ & 58.24 & 5.92 & 35.8 & $\mathrm{SC}$ & 0.17 & 1.02 & 61.51 & 0.37 \\
\hline & BA & $5 / 8-23$ & 46.24 & 4.92 & 48.8 & $\mathrm{SC}$ & 0.15 & nd & nd & 2.56 \\
\hline & Bt1 & $23-42$ & 34.24 & 1.92 & 63.8 & $\mathrm{C}$ & 0.03 & 1.20 & 54.72 & 1.69 \\
\hline & $\mathrm{Bt} 2$ & $42-88$ & 30.24 & 2.92 & 66.8 & $\mathrm{C}$ & 0.04 & 1.02 & 61.51 & 2.15 \\
\hline & Bt3 & $88-185+$ & 28.24 & 2.92 & 68.8 & $\mathrm{C}$ & 0.04 & nd & nd & 1.94 \\
\hline \multirow{4}{*}{ UYOLE-P1 } & Ap & $0-19 / 25$ & 56.24 & 24.92 & 18.8 & SL & 1.33 & 0.86 & 67.55 & 2.83 \\
\hline & Bw1 & $19 / 25-60 / 86$ & 48.24 & 22.92 & 28.8 & SCL & 0.80 & 0.97 & 63.40 & 2.38 \\
\hline & $\mathrm{C}$ & $60 / 86-125 / 131$ & 82.24 & 8.92 & 8.8 & LS & 1.01 & 0.47 & 82.26 & 0.60 \\
\hline & $\mathrm{Ab} / \mathrm{Bw} 2 \mathrm{~b}$ & $125 / 131-210+$ & 68.24 & 16.92 & 14.8 & SL & 1.14 & 1.17 & 55.58 & 0.46 \\
\hline
\end{tabular}

Note: Porosity $=\left(1-[\right.$ Bulk density $/$ Particle density $] \mathrm{x} \mathrm{100)}$ assuming particle density of $2.65 \mathrm{~g} / \mathrm{cm}^{3}$

\subsubsection{Soil Porosity}

Total soil porosity is the percentage of the fraction of soil bulk density and particle density which reflects on the physical condition and the structure of the soil $[42,40]$. An increase in bulk density would decrease soil porosity and consequently hamper aeration and restrict water infiltration rate. Pedons SUARAT-P1 and UYOLE-P1 have a normal and favorable range (40-70\%) of total soil porosity in their topsoil and subsoil horizons $[42,40]$ which indicate a good aeration and water infiltration. Thus the values of total porosity observed in the studied pedons pose no limitation to root penetration and water movement [42].

\subsubsection{Soil Penetration Resistance}

Penetration resistance (PR) is a measure of the soil strength, compactness or cohesiveness [29] which depends on the moisture of the soil and has some relationship with plant root growth [30]. In pedon SUARAT-P1 penetration resistance values showed an irregular pattern of change with depth from $0.37 \mathrm{MPa}$ in topsoil to $2.56,1.69,2.15$ and $1.94 \mathrm{MPa}$ respectively in the $\mathrm{BA}, \mathrm{Bt} 1, \mathrm{Bt} 2$ and $\mathrm{Bt} 3$ horizons. On the other hand, penetration resistance values in pedon UYOLE-P1 showed a decreasing trend from $2.83 \mathrm{MPa}$ in topsoil to 2.38, 0.60 , and $0.46 \mathrm{MPa}$ respectively in the subsoil horizons. Literature suggests that penetration resistance values of $<0.5$ $\mathrm{MPa}$ are rated as loose, $0.5-1.25 \mathrm{MPa}$ as medium, 1.25-2.0 $\mathrm{MPa}$ as dense, 2.00-3.00 MPa as very dense; and > 3.00 MPa as extremely dense. In terms of limitation to root growth such rating is translated as follows in the same order: root growth not affected, root growth of some cereal plants may be affected, cereal root growth badly affected, very few plant roots penetrate the soil, and root growth virtually ceases [30]. Therefore, root penetration at Magadu site (SUARAT-P1) in topsoil layer would be easy and development / growth of shallow-rooted plants is not impaired, whereas roots of deep-rooted plants might find it difficult to penetrate down the subsoil. In the case of Uyole site (UYOLE-P1), limitation to root growth can be rated as more severe than in pedon SUARAT-P1.

\subsection{Soil Chemical Characteristics}

Selected soil chemical properties of the studied pedons are shown in Table 4.

\subsubsection{Soil pH and Electrical Conductivity (EC)}

Soil $\mathrm{pH}$ is a measure of the values of hydrogen ions $(\mathrm{H}+)$ and hydroxyl ions (OH-) present to indicate soil acidity or alkalinity [30]. The topsoil $\mathrm{pH}$ of both sites was slightly acidic, but pedon SUARAT-P1 subsoil abruptly changed to very strongly acidic (4.5-5.0) [43] while pedon UYOLE-P1 subsoil with $\mathrm{pH}$ values 6.66 and 7.28 in the subsoil horizons and were rated as having neutral $\mathrm{pH}$ while the last horizon with $\mathrm{pH}$ of 5.65 was rated as medium acidic. According to Ricardo and Yost [44] soils with very strongly acidic conditions may cause $\mathrm{Mn}$ and / or Al toxicity or otherwise $\mathrm{Ca}$ and $\mathrm{Mg}$ deficiency would be observed in some crops like sorghum and soybean. Furthermore, micronutrient deficiencies of the likes of $\mathrm{Zn}$ or $\mathrm{Fe}$ is possible in high $\mathrm{pH}$ soils $[44,40]$ in which Fe under high $\mathrm{pH}$ is changed to less soluble form [40].

Uyole site might be very suitable for most crops as the $\mathrm{pH}$ in topsoil and subsoil down to $135 \mathrm{~cm}$ are within $\mathrm{pH}$ ranges which support many crops [8]. The Magadu site might be very suitable for shallow rooted crops within $8 \mathrm{~cm}$ (top horizon ends at $8 \mathrm{~cm}$ ) while subsoils (starting at $8-23 \mathrm{~cm}$ ) was very strongly acid, a condition which might impair availability of most nutrients to plants with deep roots. The $\mathrm{pH}_{\mathrm{KCl}}$ values of both sites were lower than $\mathrm{pH}_{\mathrm{H} 2 \mathrm{O}}$ values and according to Ricardo and Yost [44] and Msanya et al. [8] such soils are said to have net negative charge and are cation exchanger.

On the other hand, electrical conductivity (EC) predicts extent of salinity levels of a soil [30] in a soil:water suspension (EC1:2.5). Electrical conductivity of pedon SUARAT-P1 was $0.34 \mathrm{dSm}-1$ in topsoil and decreased with depth to very low levels down to $0.04 \mathrm{dSm}^{-1}$ in the subsoil, indicating that the soil is not having salinity problem $(<1.7 \mathrm{dSm}-1)$ [43, 8]. Similarly, the UYOLE-P1 pedon had very low EC values $<1.7$ $\mathrm{dSm}-1$. Thus, both pedons do not have a limitation of salinity that is likely to cause crop yield reduction

\subsubsection{Organic Carbon (OC) and Organic Matter (OM)}

The results on organic carbon (OC) and organic matter (OM) are shown in Table 4. Organic carbon (OC) and organic matter $(\mathrm{OM})$ are inter-related entities, whereby $\mathrm{OM}$ is obtained by multiplying OC value by the factor of 1.724 [18]. It is a very important chemical parameter which predicts states of soil fertility such as water and nutrient holding capacity, and cation exchange capacity (CEC) [45]. The topsoil horizon of pedon SUARAT-P1 exhibited very low OC $(0.12 \%)$ and OM $(0.21 \%)$ 
contents, whereas pedon UYOLE-P1 had $1.50 \%$ OC and $2.59 \%$ $\mathrm{OM}$ in topsoil and was rated as medium [43]. The subsoil of pedon SUARAT-P1 had OC ranging from $0.27 \%$ (very low) to $0.95 \%$ (low) while the subsoil of pedon UYOLE-P1 had OC ranging from $0.47 \%$ (very low) to $1.13 \%$ (low). It was noted in this study that whereas OC and OM contents decreased regularly with depth in pedon UYOLE-P1, there was irregular change of $\mathrm{OC}$ and $\mathrm{OM}$ with depth in the case of pedon SUARAT-P1. On the basis of the values of OC and OM observed in this study, the soil fertility status of both study sites can generally be rated as poor to marginal.

Table 4. Some chemical properties of Magadu and Uyole Sites, Tanzania.

\begin{tabular}{|c|c|c|c|c|c|c|c|c|c|c|}
\hline \multirow{2}{*}{ Profile } & \multirow{2}{*}{ Horizon } & \multirow{2}{*}{ Depth (cm) } & \multicolumn{2}{|l|}{ pH } & \multirow{2}{*}{$\begin{array}{l}\text { EC } \\
\mathrm{dS} / \mathrm{m}\end{array}$} & \multirow{2}{*}{$\begin{array}{l}\text { OC } \\
\% \\
\end{array}$} & \multirow[t]{2}{*}{$\mathbf{O M}$} & \multirow[t]{2}{*}{$\mathbf{T N}$} & \multirow[t]{2}{*}{$\mathrm{C} / \mathrm{N}$ ratio } & \multirow{2}{*}{$\begin{array}{l}\text { Available P } \\
\mathrm{mg} \mathrm{kg}^{-1}\end{array}$} \\
\hline & & & $\mathrm{H}_{2} \mathrm{O}$ & $\mathrm{KCl}$ & & & & & & \\
\hline \multirow{5}{*}{ SUARAT-P1 } & $\mathrm{Ah}$ & $0-5 / 8$ & 6.54 & 6.03 & 0.34 & 0.12 & 0.21 & 0.11 & 1.1 & 2.56 \\
\hline & BA & $5 / 8-23$ & 4.56 & 3.90 & 0.10 & 0.95 & 1.64 & 0.10 & 9.5 & 1.48 \\
\hline & Bt1 & $23-42$ & 4.79 & 3.79 & 0.06 & 0.53 & 0.91 & 0.11 & 4.8 & 7.14 \\
\hline & $\mathrm{Bt} 2$ & $42-88$ & 4.46 & 3.91 & 0.08 & 0.27 & 0.47 & 0.08 & 3.4 & 2.56 \\
\hline & $\mathrm{Bt} 3$ & $88-185+$ & 5.00 & 3.94 & 0.04 & 0.30 & 0.52 & 0.07 & 4.3 & 1.48 \\
\hline \multirow{3}{*}{ UYOLE-P1 } & Ap & $0-19 / 25$ & 6.35 & 5.56 & 0.06 & 1.50 & 2.59 & 0.12 & 12.5 & 7.14 \\
\hline & $\mathrm{C}$ & $60 / 86-125 / 131$ & 7.28 & 5.65 & 0.06 & 0.95 & 1.64 & 0.05 & 19.0 & 0.30 \\
\hline & $\mathrm{Ab} / \mathrm{Bw} 2 \mathrm{~b}$ & $125 / 131-210+$ & 5.65 & 5.65 & 0.05 & 0.47 & 0.81 & 0.06 & 7.8 & 8.55 \\
\hline
\end{tabular}

\subsubsection{Total Nitrogen (TN), C:N Ratio and Available Phosphorus}

Nitrogen is one of the most limiting nutrients to many crops and is very important for plant growth and development. The results on total nitrogen levels are shown in Table 4. Pedon SUARAT-P1 had in the topsoil and in the subsequent two subsoil horizons TN levels rated as low $(0.10-0.11 \%)$. The deeper subsoil with TN values of 0.08 and $0.07 \%$ were classified as very low $(<0.1 \%)[43]$. The UYOLE-P1 pedon had low level of $\mathrm{TN}$ in the topsoil $(0.12 \%)$ and very low across the remaining subsoil horizons (with values of $0.08,0.05$ and $0.06 \%$ ). The observed values of $\mathrm{TN}$ call for the need for reconstitution of both studied soils with amendments and /or management to enhance soil $\mathrm{N}$ for example through crop residue incorporation, no tilling and growing of leguminous cover crops.

The $\mathrm{C}: \mathrm{N}$ ratio shows quality of organic matter in relation to nitrogen content $[43,40,30]$. It is an important parameter which shows the effect of mineralization of applied crop residues on soil nitrogen levels [30]. The $\mathrm{C}: \mathrm{N}$ ratio of topsoil in SUARAT-P1 pedon was 1.09 which is an indication of high rate of decomposition or humification of soil OM [46] while subsoil horizons had varied $\mathrm{C}: \mathrm{N}$ ratios ranging from 9.5 in $\mathrm{BA}$ horizon reflecting good quality organic matter $(\mathrm{C}: \mathrm{N}$ ratio 8 13) to $\mathrm{C}: \mathrm{N}$ ratio of 3.4 (outside the good quality range of $\mathrm{OM}$ ). On the other hand UYOLE-P1 pedon had C:N ratio of 12.5 in topsoil as good quality $\mathrm{OM}(\mathrm{C}: \mathrm{N}$ ratio 8 - 13) implying lesser humification than in the two underlying subsoil horizons with $\mathrm{C}: \mathrm{N}$ ratios of 14.1 and 19.0 implying moderate quality OM and $\mathrm{C}: \mathrm{N}$ ratio of 7.8 in the deepest horizon reflecting good quality soil organic matter [43].

According to some workers [47], the C:N ratio might not be a good parameter to evaluate soil fertility and therefore it is suggested in this regard to use separately the $\mathrm{N}$ and $\mathrm{C}$ values for more useful interpretation.

The available phosphorus contents in the studied pedons changed irregularly with depth. In pedon SUARAT-P1 levels of $\mathrm{P}$ ranged from $1.48 \mathrm{mg} \mathrm{kg}^{-1}$ (low) to $7.14 \mathrm{mg} \mathrm{kg}^{-1}$ (medium).
A major part of the solum had $\mathrm{P}$ levels of $<7 \mathrm{mg} \mathrm{kg}^{-1}$ which means that pedon SUARAT-P1 can generally be rated as having low levels of available $\mathrm{P}$. The low levels of $\mathrm{P}$ in this pedon may be due to the very strong acid conditions ( $\mathrm{pH} 4.5-$ 5.0) causing fixation and unavailability of $P$. The soil most likely has very large quantities of reactive iron and / or aluminum compounds and these together with the large amounts of clay are responsible for the $\mathrm{P}$ fixation process and hence the unavailability of $\mathrm{P}$ [30]. The topsoil of pedon UYOLE-P1 had medium levels of available P (7.14 mg kg-1) which may be sufficient for plant growth. However, with this amount of $\mathrm{P}$ and the fact that a major part of the subsoil below the topsoil had low available $\mathrm{P}\left(<7.0 \mathrm{mg} \mathrm{kg}^{-1}\right)$, $\mathrm{P}$-deficiency is likely to occur in most crops [6]. The unavailability of $\mathrm{P}$ in a major part of the subsoil of pedon UYOLE-P1 might be due to leaching and / or nature of the soil parent materials [6] or due to $\mathrm{pH}$ which exceeded 7.0 [40].

\subsubsection{Exchangeable Bases and Cation Exchange Capacity (CEC)}

The amounts of exchangeable bases in the studied pedons are presented in Table 4. The SUARAT-P1 pedon (clayey soil) had $\mathrm{Ca}$ levels varying from medium $\left(5.1-10 \mathrm{cmol}(\mathrm{c}) \mathrm{kg}^{-1}\right)$ in topsoil to low $\left(2.0-5.0 \mathrm{cmol}(\mathrm{c}) \mathrm{kg}^{-1}\right)$ and very low $(<2.0$ cmol(c) $\mathrm{kg}^{-1}$ ) in subsoil horizons according to the rating by Msanya et al. [43]. The UYOLE-P1 pedon (loamy soil) on the other hand had very high levels of $\mathrm{Ca}\left(>6.0 \mathrm{cmol}(\mathrm{c}) \mathrm{kg}^{-1}\right)$ in the upper two horizons and medium to high levels in the last two subsoil horizons respectively. The high $\mathrm{Ca}$ levels may likely diminish P availability in the soil [40], and therefore the soil might call for some management strategies to address this.

Exchangeable $\mathrm{Mg}$ in SUARAT-P1 pedon (clayey soil) is rated as medium throughout the soil profile with $\mathrm{Mg}$ levels 1.1 - $3.0 \mathrm{cmol}(\mathrm{c}) \mathrm{kg}^{-1}$, while in the UYOLE-P1 pedon (loamy soil) $\mathrm{Mg}$ was high in topsoil (2.11 $\left.\mathrm{cmol}(\mathrm{c}) \mathrm{kg}^{-1}\right)$ and in subsoil

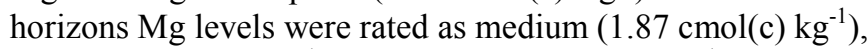
low $\left(0.68 \mathrm{cmol}(\mathrm{c}) \mathrm{kg}^{-1}\right)$ and high $\left(2.51 \mathrm{cmol}(\mathrm{c}) \mathrm{kg}^{-1}\right)$ in the last subsoil horizon. High amounts of $\mathrm{Mg}$ in topsoil of the pedon might be associated with less leaching of this element to 
subsoil horizons [6].

Exchangeable $\mathrm{K}$ levels decreased regularly with depth in pedon SUARAT-P1 while there was irregular change of $\mathrm{K}$ with depth in pedon UYOLE-P1. In pedon SUARAT-P1 (clayey) exchangeable $\mathrm{K}$ ranged from medium $(0.61 \mathrm{cmol}(\mathrm{c})$ $\left.\mathrm{kg}^{-1}\right)$ to very high $\left(2.62 \mathrm{cmol}(\mathrm{c}) \mathrm{kg}^{-1}\right)$ in topsoil and ranged from very low $\left(0.12 \mathrm{cmol}(\mathrm{c}) \mathrm{kg}^{-1}\right)$ to low $\left(0.37 \mathrm{cmol}(\mathrm{c}) \mathrm{kg}^{-1}\right)$ in subsoil [43]. In UYOLE-P1 pedon (loamy), the $\mathrm{K}$ levels ranged from 2.06 to $7.40 \mathrm{cmol}(\mathrm{c}) \mathrm{kg}^{-1}$ and were rated as very high $\left(>1.35 \mathrm{cmol}(\mathrm{c}) \mathrm{kg}^{-1}\right)$ throughout the profile depth.

Exchangeable sodium $(\mathrm{Na})$ at Magadu profile (SUARAT-P1) was rated as low throughout the profile with $\mathrm{Na}$ levels in between $0.10-0.30 \mathrm{cmol}(\mathrm{c}) \mathrm{kg}^{-1}$ [43]. In UYOLE-P1 pedon Na levels ranged from $0.49 \mathrm{cmol}(\mathrm{c}) \mathrm{kg}^{-1}$ (medium) in topsoil to $1.19 \mathrm{cmol}(\mathrm{c}) \mathrm{kg}^{-1}$ (high) in the major part of the subsoil and then jumped to $8.63 \mathrm{cmol}(\mathrm{c}) \mathrm{kg}^{-1}$ (very high) in the deeper subsoil.

Table 5. Exchangeable bases and related properties of the studied pedons of Magadu and Uyole Sites, Tanzania.

\begin{tabular}{|c|c|c|c|c|c|c|c|c|c|c|c|c|c|}
\hline \multirow{2}{*}{ Profile } & \multirow{2}{*}{ Horizon } & \multirow{2}{*}{ Depth (cm) } & $\mathrm{Ca}^{2+}$ & $\mathrm{Mg}^{2+}$ & $\mathbf{K}^{+}$ & $\mathrm{Na}^{+}$ & $\mathbf{A l}^{3+}$ & $\mathbf{H}^{+}$ & TEB & $\mathrm{CEC}_{\text {soil }}$ & $\mathrm{CEC}_{\text {clay }}$ & PBS & ESP \\
\hline & & & \multicolumn{11}{|c|}{ cmol(c) $\mathrm{kg}^{-1}$} \\
\hline \multirow{5}{*}{ SUARAT-P1 } & $\mathrm{Ah}$ & $0-5 / 8$ & 7.9 & 2.99 & 2.62 & 0.13 & 0.00 & 0.04 & 13.64 & 14.60 & 39.61 & 93.42 & 0.89 \\
\hline & BA & $5 / 8-23$ & 2.35 & 1.17 & 0.61 & 0.06 & 2.00 & 1.24 & 4.19 & 13.20 & 20.37 & 31.70 & 0.45 \\
\hline & $\mathrm{Bt} 1$ & $23-42$ & 2.96 & 1.11 & 0.37 & 0.06 & 1.95 & 1.46 & 4.50 & 13.40 & 18.15 & 33.58 & 0.45 \\
\hline & $\mathrm{Bt} 2$ & $42-88$ & 2.04 & 1.15 & 0.14 & 0.10 & 2.00 & 1.58 & 3.43 & 12.40 & 17.19 & 27.66 & 0.81 \\
\hline & $\mathrm{Bt} 3$ & $88-185+$ & 1.73 & 1.31 & 0.12 & 0.21 & 1.96 & 1.58 & 3.37 & 23.20 & 32.21 & 14.53 & 0.91 \\
\hline \multirow{4}{*}{ UYOLE-P1 } & Ap & $0-19 / 25$ & 6.67 & 2.11 & 2.37 & 0.49 & 0.00 & 0.12 & 11.76 & 21.00 & 108.94 & 55.43 & 2.33 \\
\hline & Bw1 & $19 / 25-60 / 86$ & 8.21 & 1.87 & 6.39 & 1.16 & 0.00 & 0.08 & 17.71 & 34.00 & 104.58 & 51.85 & 3.41 \\
\hline & $\mathrm{C}$ & $60 / 86-125 / 131$ & 3.58 & 0.68 & 2.06 & 1.19 & 0.00 & 0.26 & 7.77 & 15.00 & 141.86 & 47.53 & 7.93 \\
\hline & $\mathrm{Ab} / \mathrm{Bw} 2 \mathrm{~b}$ & $125 / 131-210+$ & 5.43 & 2.51 & 7.40 & 8.63 & 0.00 & 0.06 & 24.03 & 26.00 & 164.73 & 92.19 & 31.9 \\
\hline
\end{tabular}

PBS $=$ Percent base saturation ESP $=$ Exchangeable sodium percent.

Sodium levels are important to forecast soil sodicity which is a more important parameter than the absolute level of exchangeable $\mathrm{Na}[43]$.

\subsubsection{Soil Sodicity}

Soil sodicity is the measure of amount of exchangeable sodium present in the soil and is calculated as amount of exchangeable sodium as a percentage of the cation exchange capacity [43], [30].

$$
\mathrm{ESP}=(\text { exchangeable } \mathrm{Na}) /(\mathrm{CEC}) \times 100
$$

According to Hazelton and Murphy [30], sodic soils may cause different soil problems including, very low infiltration, very hard and dense subsoils, clay dispersion and vulnerability to soil tunneling. All horizons of SUARAT-P1 pedon had ESP $<1$ which is indicative of a non-sodic soil. In fact, according to Msanya et al. [43] and Hazelton and Murphy [30], all soils with ESP $<6$ are categorized as non-sodic and these are suitable for crop production and do not have problems of soil dispersion. The UYOLE-P1 pedon is also rated as non-sodic in its epipedon and the underlying subsurface horizon (ESP 2.33 and 3.41). However, the third and fourth horizons had ESP of 7.93 and 31.9 and were rated as slightly sodic and very strongly sodic respectively. The results suggest that the soil can be used for crop production with no or very little impact on crop yield reduction [43]. This is particularly so when considering the upper $60 \mathrm{~cm}$ or so of the profile which is non-sodic.

\subsubsection{Cation Exchange Capacity (CEC)}

The cation exchange capacity (CEC) is the ability of the soil to hold on against leaching and exchange of cations [43, 30]. CEC is very important in regulating / buffering $\mathrm{pH}$ in soils; the higher the CEC the lower the acidification. A soil with low CEC acidifies very quickly [30]. The CEC values of all horizons of SUARAT-P1 pedon were rated as medium (12.1 $25 \mathrm{cmol}(\mathrm{c}) \mathrm{kg}^{-1}$ ) [43]. The highest CEC of $23.2 \mathrm{cmol}(\mathrm{c}) \mathrm{kg}^{-1}$ was observed in the illuvial $\mathrm{Bt} 3$ horizon (the deepest) with the highest clay content. In the UYOLE-P1 pedon, the CEC was generally higher than in the SUARAT-P1 pedon with topsoil value of $21 \mathrm{cmol}(\mathrm{c}) \mathrm{kg}^{-1}$ (medium), then in the subsoil horizon Bw1 a value of $34 \mathrm{cmol}(\mathrm{c}) \mathrm{kg}^{-1}$ (high) was recorded, followed by a value of $15 \mathrm{cmol}(\mathrm{c}) \mathrm{kg}^{-1}$ (medium) in the $\mathrm{C}$ horizon and lastly a jump to $26 \mathrm{cmol}(\mathrm{c}) \mathrm{kg}^{-1}$ (high) in the deepest horizon. The levels of CEC observed in this study particularly for pedon SUARAT-P1 are not adequate and may need to be improved for sustainable crop production for example through organic matter addition [30].

$\mathrm{CEC}_{\text {clay }}$ is an essential indicator of weathering development and the dominant clay mineral type in a soil [48]. The SUARAT-P1 pedon had in general lower CECclay values than the UYOLE-P1 pedon. Similar trend was observed for $\mathrm{CEC}_{\text {soil }}$ $\mathrm{CEC}_{\text {clay }}$ in SUARAT-P1 pedon ranged from $17.19 \mathrm{cmol}(\mathrm{c}) \mathrm{kg}^{-1}$ in the $\mathrm{Bt} 2$ horizon to $39.61 \mathrm{cmol}(\mathrm{c}) \mathrm{kg}^{-1}$ in the epipedon (Ah horizon). The values of $\mathrm{CEC}_{\text {clay }}$ observed in pedon SUARAT-P1 reflect a mixed clay mineralogy comprising dominantly kaolinite but may contain trace amounts of some 2:1 silicate clay minerals. The dominance of kaolinite (1:1 silicate clay mineral) in SUARAT-P1 pedon is typical of advanced weathering. The UYOLE-P1 pedon on other hand had high $\mathrm{CEC}_{\text {clay }}$ between 108.94 - $164.73 \mathrm{cmol}(\mathrm{c}) \mathrm{kg}^{-1}$ indicating the presence of 2:1 clay minerals most probably smectite $[49,51,52,53]$. Smectite clay is formed from two tetrahedral silica and single octahedral alumina (2:1 clay) which according to Conklin [50], occurs in younger and less weathered soils. The results in this study clearly indicate therefore that the SUARAT-P1 pedon has shown more advanced stage of weathering than UYOLE-P1 pedon by having both lower CECsoil and CECclay values [48]. 


\subsubsection{Base Saturation (BS)}

Base saturation refers to percentage ratio of sum of basic cations $(\mathrm{Ca}, \mathrm{Mg}, \mathrm{K}$, and $\mathrm{Na}$ ) to its cation exchange capacity (CEC) and is used as an indicator of soil fertility. Base saturation in topsoil of SUARAT-P1 pedon was $93.42 \%$ and was rated very high while in all the remaining horizons it was rated as low [30] with all values $<50 \%$. In the UYOLE-P1 pedon, the upper three horizons can be rated as having medium levels of BS while the last horizon was rated as having very high BS (92.19\%). According to Hazelton and Murphy [30], in the SUARAT-P1 pedon, there must have been stronger leaching of the basic cations even beyond the profile depth than in the case of the UYOLE-P1 pedon.

\subsubsection{Cation Ratios and Nutrient Balance in the Studied Pedons}

The relative proportions of the basic cations $(\mathrm{Ca}, \mathrm{Mg}, \mathrm{K}$, and $\mathrm{Na}$ ) are important in the availability of individual cations in the soil and plant uptake [55]. Plant accessibility of one cation is not exclusively depending on its availability but rather on the optimal proportion of other cations [56, 55]. The nutrient ratios in the studied pedons are presented in Table 6 . In pedon SUARAT-P1, the $\mathrm{Ca} / \mathrm{Mg}$ ratios in the upper $40 \mathrm{~cm}$ of the pedon were favorable $(2-4)$ for plant growth [43]. The last two horizons had $\mathrm{Ca} / \mathrm{Mg}$ ratios of less than 2, and hence not favorable. In UYOLE-P1 pedon only the $\mathrm{Ca} / \mathrm{Mg}$ ratios in topsoil and the last horizon were favorable for plant growth.
The other two horizons had ratios higher than the optimal, implying that they will hinder $\mathrm{Mg}$ plant uptake [6]. Moreover, when $\mathrm{Ca} / \mathrm{Mg}$ ratio exceeds $5: 1$, it may cause $\mathrm{Mg}$ and $\mathrm{P}$ deficiency in plants [40]. Considering topsoils, the $\mathrm{Ca} / \mathrm{Mg}$ ratios in the two studied soils may not be a problem to crop growth and development. The $\mathrm{Mg} / \mathrm{K}$ ratios varied between 1.14 and 10.92 and increased down the profile in SUARAT-P1 pedon. According to Msanya et al. [43] favorable range of $\mathrm{Mg} / \mathrm{K}$ ratios for most crops range from $1-4$. Considering the upper $40 \mathrm{~cm}$ of the soil, the $\mathrm{Mg} / \mathrm{K}$ ratios are favorable for crop production. With regard to the UYOLE-P1 pedon, the $\mathrm{Mg} / \mathrm{K}$ ratios were smaller than the prescribed optimal range of $1-4$, suggesting that that the soil will have a problem with K supply. However, care must also be taken on the interpretation of results on $\mathrm{Mg} / \mathrm{K}$ ratios as Loide [57] pointed out that different thresholds of $\mathrm{Mg} / \mathrm{K}$ ratios depended on soil textures and on method of cation extraction. The topsoil $\mathrm{Ca} / \mathrm{TEB}$ ratios of both SUARAT-P1 and UYOLE-P1 pedons had values of 0.58 and 0.57 respectively. They were slightly $>0.5$. According to Landon [40], there will be a slight shortage of either $\mathrm{Mg}$ and / or $\mathrm{K}$ as $\mathrm{Ca}$ /TEB value exceeding 0.5 would signify difficulty in their uptake by plants.\% $(\mathrm{K} / \mathrm{TEB})$ values $>2.0 \%$ are favorable for most tropical crops according to Landon, [40]. The\% (K/TEB) values observed in both SUARAT-P1 and UYOLE-P1 pedons conform to this condition and hence the two pedons are favorable for most tropical crops.

Table 6. Cation ratios and nutrient balance in the studied pedons of Magadu and Uyole sites, Tanzania.

\begin{tabular}{|c|c|c|c|c|c|c|}
\hline Profile & Horizon & Depth (cm) & $\mathrm{Ca} / \mathrm{Mg}$ & $\mathrm{Mg} / \mathrm{K}$ & $\mathrm{Ca} / \mathrm{TEB}$ & $\%($ K/TEB $)$ \\
\hline \multirow{5}{*}{ SUARAT-P1 } & Ah & $0-5 / 8$ & 2.64 & 1.14 & 0.58 & 19.15 \\
\hline & BA & $5 / 8-23$ & 2.01 & 1.92 & 0.32 & 8.21 \\
\hline & Bt1 & $23-42$ & 2.67 & 3.00 & 0.37 & 4.68 \\
\hline & Bt2 & $42-88$ & 1.77 & 8.21 & 0.29 & 2.00 \\
\hline & Bt3 & $88-185+$ & 1.32 & 10.92 & 0.25 & 1.74 \\
\hline \multirow{3}{*}{ UYOLE-P1 } & Ap & $0-19 / 25$ & 3.16 & 0.89 & 0.57 & 20.15 \\
\hline & Bw1 & $19 / 25-60 / 86$ & 4.39 & 0.29 & 0.46 & 36.08 \\
\hline & $\mathrm{Ab} / \mathrm{Bw} 2 \mathrm{~b}$ & $125 / 131-210+$ & 2.16 & 0.34 & 0.23 & 30.79 \\
\hline
\end{tabular}

\subsubsection{Extractable Micronutrients in the Studied Pedons}

Micronutrients are very important for the growth of different crops [58]. Their availability in soils is affected by a number of factors including $\mathrm{pH}$, soil texture, CEC, EC, OM, oxidation-reduction reactions, temperature, moisture and light $[59,58,40]$.

The results on essential micronutrients in the studied pedon are presented in Table 7 . The micronutrient contents were in the order of $\mathrm{Mn}>\mathrm{Fe}>\mathrm{Zn}>\mathrm{Cu}$ in SUARAT-P1 and UYOLE-P1 pedons as it appears in the general order in plant accumulation [58]. The SUARAT-P1 pedon had copper $(\mathrm{Cu})$ levels in topsoil and subsoil horizons between $0.48-1.33 \mathrm{mg}$ $\mathrm{kg}^{-1}$ which were rated as medium and exceeded deficiency level [59, 60], while UYOLE-P1 pedon had $\mathrm{Cu}$ values between $0.16-0.37 \mathrm{mg} \mathrm{kg}^{-1}$ being rated medium in topsoil and low in subsoil. According to Landon [40], its availability among other things is controlled primarily by total soil $\mathrm{Cu}$, high $\mathrm{P}$ and Zn. SUARAT-P1 topsoil registered high level of zinc $(\mathrm{Zn})$ concentration while in subsoil horizons it ranged from $0.02-0.48 \mathrm{mg} \mathrm{kg}^{-1}$ and was rated as low zinc concentration. On the other hand, topsoil and underlying horizons of UYOLE-P1 registered high level of zinc [60] exceeding the deficiency $\mathrm{Zn}$ levels [40]. The high levels of $\mathrm{Zn}$ in UYOLE-P1 pedon might have been the reason for the low $\mathrm{Cu}$ concentrations [40]. Manganese (Mn) had higher concentration levels than all the other micronutrients in both sites with amounts exceeding the deficiency level of $<2-5$ $\mathrm{mg} \mathrm{kg}^{-1}$ [59]. In SUARAT-P1 pedon, Mn levels ranged from $7.67-94.17 \mathrm{mg} \mathrm{kg}^{-1}$ with the highest amount in topsoil. The amounts showed a regular decreasing trend with depth. Similar trend was observed elsewhere by Merumba et al. [60]. In the case of UYOLE-P1 pedon, the highest Mn concentration of $134.1 \mathrm{mg} \mathrm{kg}{ }^{-1}$ was observed in the $\mathrm{Bw}$ horizon while the least concentration of $30.35 \mathrm{mg} \mathrm{kg}^{-1}$ was observed in the deepest horizon. However, both sites were rated as having high levels of $\mathrm{Mn}$ in all horizons [60]. Iron (Fe), similarly had higher values than the deficiency level of 
$2.5-4.5 \mathrm{mg} \mathrm{kg}^{-1}$ [40], and ranged between $8.27-62.47 \mathrm{mg}$ $\mathrm{kg}^{-1}$ in SUARAT-P1 and between $26.54-111.19 \mathrm{mg} \mathrm{kg}^{-1}$ in UYOLE-P1 pedon.

Both pedons had sufficient amounts of the essential micro-elements, but as Landon [40] cautioned, some cereal crops and vegetables are very sensitive to copper deficiency; therefore, depending on specific critical levels of different crops, there might be need to add some copper in UYOLE soil depending on specific crop requirement for $\mathrm{Cu}$.

\subsubsection{Total Elemental Composition and Weathering Indices/Ratios of the Studied Soils}

The total elemental composition of the two soils is presented in Table 8. The most abundant elemental oxides were in the order of $\mathrm{SiO}_{2}>\mathrm{Fe}_{2} \mathrm{O}_{3}>\mathrm{Al}_{2} \mathrm{O}_{3}>\mathrm{TiO}_{2}>\mathrm{P}_{2} \mathrm{O}_{5}>\mathrm{K}_{2} \mathrm{O}>$ $\mathrm{CaO}$ for SUARAT-P1 pedon and $\mathrm{SiO}_{2}>\mathrm{Al}_{2} \mathrm{O}_{3}>\mathrm{Fe}_{2} \mathrm{O}_{3}>\mathrm{K}_{2} \mathrm{O}>$ $\mathrm{P}_{2} \mathrm{O}_{5}>\mathrm{TiO}_{2}>\mathrm{CaO}$ for UYOLE-P1 pedon.

The amount of silica $\left(\mathrm{SiO}_{2}\right)$ in SUARAT-P1 pedon in the upper, middle and bottom horizons were 71.55, 72.01, $80.03 \%$ respectively, increasing down the pedon, whereas in the UYOLE-P1 pedon, $\mathrm{SiO}_{2}$ increased from $74.24 \%$ in the upper horizon to $80.71 \%$ in the middle horizon, and then decreased to $71.36 \%$ in the bottom horizon. The high $\mathrm{SiO}_{2}$ content in both two sites is a reflection of the large amounts of quartz mineral in SUARAT-P1 pedon and amorphous silica in UYOLE-P1 pedon $[1,3,60]$. The high $\mathrm{SiO}_{2}$ content of the Bw1 horizon in the UYOLE-P1 pedon may be attributed to the large amount of pumice fragments found in the horizon [61].

The $\mathrm{Al}_{2} \mathrm{O}_{3}$ content ranged from 7.13 to $10.32 \%$ in SUARAT-P1 pedon, while in UYOLE-P1 pedon, $\mathrm{Al}_{2} \mathrm{O}_{3}$ content ranged from 7.13 to $8.36 \%$. Generally speaking, SUARAT-P1 pedon had higher content of $\mathrm{Al}_{2} \mathrm{O}_{3}$ than UYOLE-P1 pedon. The $\mathrm{Fe}_{2} \mathrm{O}_{3}$ content of SUARAT-P1 pedon ranged from 4.92 to $11.64 \%$ while that of UYOLE-P1 pedon ranged from 3.76 to $8.81 \%$. Just like for $\mathrm{Al}_{2} \mathrm{O}_{3}$ content, SUARAT-P1 pedon had generally higher $\mathrm{Fe}_{2} \mathrm{O}_{3}$ content than
UYOLE-P1 pedon. Higher content of both $\mathrm{Al}_{2} \mathrm{O}_{3}$ and $\mathrm{Fe}_{2} \mathrm{O}_{3}$ in SUARAT-P1 pedon than in UYOLE-P1 pedon is related to higher content of sesquioxides in the former pedon than in the latter pedon. SUARAT-P1 pedon was more highly weathered and hence had higher content of sesquioxides than UYOLE-P1 pedon.

The other oxides including $\mathrm{K}_{2} \mathrm{O}, \mathrm{CaO}, \mathrm{TiO}_{2}$ and $\mathrm{P}_{2} \mathrm{O}_{5}$ detected in the two pedons were as low as $5 \%$, and the low levels may be due to their leaching out of the profile after weathering processes or may be due to the nature of the soil parent materials [62].

The $\mathrm{SiO}_{2} / \mathrm{Al}_{2} \mathrm{O}_{3}$ ratio also known as Ruxton Ratio (RR) was introduced/suggested by Ruxton [63], which assumed alumina and other sesquioxides to be immobile during the process of weathering. In the SUARAT-P1 pedon, the $\mathrm{SiO}_{2} / \mathrm{Al}_{2} \mathrm{O}_{3}$ ratio in surface and middle horizons showed almost similar ratios (6.93 and 6.73) but the deepest horizon had value of 11.27 which was higher than that in upper horizons, implying that more weathering occurred in topsoils than in bottom soil horizons [64]. In the case of UYOLE-P1 pedon, the trend was different in which topsoil and bottom soils had almost similar ratio (8.92 and 8.54) while the middle horizons had higher ratio due to the presence of sizeable amounts of pumices weathering to more silicates minerals as proposed by Gama-Castro et al. [61]. The ratio of $\mathrm{SiO}_{2} /\left(\mathrm{Fe}_{2} \mathrm{O}_{3}+\mathrm{Al}_{2} \mathrm{O}_{3}\right)$ which is also known as silica- sesquioxide ratio in SUARAT-P1 pedon was $3.41,3.22$ and 6.66 respectively in the top, middle and bottom horizons, showing a higher ratio towards the bottom indicating more weathering in the top and less weathering in the bottom horizons. In UYOLE-P1 pedon, least weathering is observed in the middle horizon with a $\mathrm{SiO}_{2} /\left(\mathrm{Fe}_{2} \mathrm{O}_{3}+\mathrm{Al}_{2} \mathrm{O}_{3}\right)$ ratio of 7.41 , whereas the top and middle horizons had ratios of respectively 5.47 and 4.16 insinuating more weathering in the bottom horizons than in the topsoils $[65,64,60]$.

Table 7. Some important extractable micro-nutrients of the studied pedons of Magadu and Uyole sites, Tanzania.

\begin{tabular}{|c|c|c|c|c|c|c|}
\hline \multirow{2}{*}{ Profile } & \multirow{2}{*}{ Horizon } & \multirow{2}{*}{ Depth (cm) } & $\mathbf{C u}$ & Zn & Mn & $\mathrm{Fe}$ \\
\hline & & & \multicolumn{4}{|c|}{$\mathrm{mg} \mathrm{kg}^{-1}$} \\
\hline \multirow{5}{*}{ SUARAT-P1 } & $\mathrm{Ah}$ & $0-5 / 8$ & 1.33 & 3.24 & 94.17 & 41.15 \\
\hline & Bt1 & $23-42$ & 1.12 & 0.15 & 35.14 & 23.49 \\
\hline & Bt2 & $42-88$ & 1.01 & 0.15 & 19.18 & 11.92 \\
\hline & $\mathrm{Bt} 3$ & $88-185+$ & 0.48 & 0.02 & 7.67 & 8.27 \\
\hline & Ap & $0-19 / 25$ & 0.37 & 7.29 & 119.70 & 91.70 \\
\hline \multirow{3}{*}{ UYOLE-P1 } & Bw1 & $19 / 25-60 / 86$ & 0.16 & 7.21 & 134.10 & 111.19 \\
\hline & $\mathrm{C}$ & $60 / 86-125 / 131$ & 0.16 & 3.16 & 39.93 & 26.54 \\
\hline & $\mathrm{Ab} / \mathrm{Bw} 2 \mathrm{~b}$ & $125 / 131-210+$ & 0.16 & 6.5 & 30.35 & 56.38 \\
\hline
\end{tabular}

Simultaneous decrease of both $\mathrm{SiO}_{2} / \mathrm{Al}_{2} \mathrm{O}_{3}$ and $\mathrm{SiO}_{2} /\left(\mathrm{Fe}_{2} \mathrm{O}_{3}\right.$ $+\mathrm{Al}_{2} \mathrm{O}_{3}$ ) ratios down the profile as revealed by SUARAT-P1 pedon is assumed to be caused by clay and / or Al and Fe movements down the profile; as opposed to their increase down the profile (from topsoil to middle horizons) as shown in UYOLEP-1 pedon, which may suggests the shifting of silicate minerals to lower horizons [65]. Results on both $\mathrm{SiO}_{2} / \mathrm{Al}_{2} \mathrm{O}_{3}$ and $\mathrm{SiO}_{2} /\left(\mathrm{Fe}_{2} \mathrm{O}_{3}+\mathrm{Al}_{2} \mathrm{O}_{3}\right)$ weathering indices of the studied pedons, SUARAT-P1 pedon showed more advanced weathering of its soil minerals than in UYOLE-P1 pedon, with lesser degree of weathering observed in UYOLE-P1 pedon which is having higher $\mathrm{SiO}_{2} / \mathrm{Al}_{2} \mathrm{O}_{3}$ ratio $[63,60]$. 
Table 8. Total elemental composition and weathering indices in the studied pedons of Magadu and Uyole sites, Tanzania.

\begin{tabular}{|c|c|c|c|c|c|c|c|c|c|c|c|}
\hline \multirow{2}{*}{ Profile } & \multirow{2}{*}{ Horizon } & \multirow{2}{*}{ Depth (cm) } & \multicolumn{5}{|c|}{ Total elemental composition \% } & \multicolumn{4}{|c|}{ Weathering Indices } \\
\hline & & & $\mathrm{SiO}_{2}$ & $\mathrm{Al}_{2} \mathrm{O}_{3}$ & $\mathrm{Fe}_{2} \mathrm{O}_{3}$ & $\mathbf{K}_{2} \mathbf{O}$ & $\mathrm{CaO}$ & $\mathrm{TiO}_{2}$ & $\mathbf{P}_{2} \mathbf{O}_{5}$ & $\mathrm{SiO}_{2} / \mathrm{Al}_{2} \mathrm{O}_{3}$ & $\mathrm{SiO}_{2} /\left(\mathrm{Al}_{2} \mathrm{O}_{3} / \mathrm{Fe}_{2} \mathrm{O}_{3}\right)$ \\
\hline \multirow{3}{*}{ SUARAT-P1 } & $\mathrm{Ah}$ & $0-5 / 8$ & 71.55 & 10.32 & 10.65 & 0.35 & 0.26 & 1.37 & 0.50 & 6.93 & 3.41 \\
\hline & Bt1 & $23-42$ & 72.01 & 10.71 & 11.64 & 0.25 & 0.19 & 1.56 & 0.65 & 6.72 & 3.22 \\
\hline & $\mathrm{Bt} 3$ & $88-185+$ & 80.03 & 7.10 & 4.92 & 2.44 & 0.75 & 0.63 & 2.14 & 11.27 & 6.66 \\
\hline \multirow{3}{*}{ UYOLE-P1 } & Ap & $0-19 / 25$ & 74.24 & 8.32 & 5.26 & 2.02 & 0.53 & 0.76 & 1.87 & 8.92 & 5.47 \\
\hline & Bw1 & $19 / 25-60 / 86$ & 80.71 & 7.13 & 3.76 & 2.33 & 0.59 & 0.51 & 0.97 & 11.32 & 7.41 \\
\hline & $\mathrm{Ab} / \mathrm{Bw} 2 \mathrm{~b}$ & $125 / 131-210+$ & 71.36 & 8.36 & 8.81 & 1.40 & 4.22 & 1.73 & 1.12 & 8.54 & 4.16 \\
\hline
\end{tabular}

\subsection{Soil Classification in the Studied Area}

Soil classification was done accordingly to USDA Soil Taxonomy [11] and correlated with the World Reference Base for Soil Resources [12] based on the results obtained in the laboratory and properties observed and described in the field. Soil diagnostic horizons and features were identified and appropriate names given following the keys provided by the two systems of classification (Tables 9 and 10).

The soil of studied area at Magadu (SUARAT-P1) as described by the USDA Soil Taxonomy was named as "Very deep, clayey, slightly acid to very strong acid, very gently sloping, ustic, isohyperthermic, Typic Kandiustults" matching in the World Reference Base for Soil Resources (WRB) with "Haplic Lixisols (Clayic, Cutanic, Ochric, Profondic)", and the Uyole pedon (UYOLE-P1) was classified as "Very deep, loamy, slightly acid to neutral, very gently sloping, Udic, Thermic, Andic Dystrudepts" in the USDA Soil Taxonomy and as "Eutric Andic Cambisols (Loamic, Colluvic, Humic)" inthe WRB.

Table 9. Diagnostic features and classification of the studied pedons of Magadu and Uyole sites, Tanzania.

\begin{tabular}{|c|c|c|c|c|c|c|c|}
\hline Pedon & $\begin{array}{l}\text { Diagnostic } \\
\text { horizon(s) }\end{array}$ & Other diagnostic features & Order & Suborder & Greatgroup & Subgroup & Family \\
\hline SUARAT-P1 & $\begin{array}{l}\text { Ochric } \\
\text { epipedon; } \\
\text { Kandic } \\
\text { Horizon }\end{array}$ & $\begin{array}{l}\text { Very deep, clayey, slightly acid } \\
\text { to very strong acid, very gently } \\
\text { sloping, ustic SMR1, } \\
\text { Isohyperthermic STR2 }\end{array}$ & Ultisols & Ustults & Kandiustults & $\begin{array}{l}\text { Typic } \\
\text { Kandiustults }\end{array}$ & $\begin{array}{l}\text { Very deep, clayey, slightly acid } \\
\text { to very strong acid, very gently } \\
\text { sloping, ustic, isohyperthermic, } \\
\text { Typic Kandiustults }\end{array}$ \\
\hline UYOLE-P1 & $\begin{array}{l}\text { Ochric } \\
\text { epipedon; } \\
\text { Cambic } \\
\text { horizon }\end{array}$ & $\begin{array}{l}\text { Very deep, loamy, slightly acid } \\
\text { to neutral, very gently sloping, } \\
\text { Udic SMR1, Thermic STR2 }\end{array}$ & Inceptisols & Udepts & Dystrudepts & $\begin{array}{l}\text { Andic } \\
\text { Dystrudepts }\end{array}$ & $\begin{array}{l}\text { Very deep, loamy, slightly acid to } \\
\text { neutral, very gently sloping, } \\
\text { udic, thermic, Andic Dystrudepts }\end{array}$ \\
\hline
\end{tabular}

$1=\mathrm{SMR}=$ Soil moisture regime, $2=\mathrm{STR}=$ Soil temperature regime.

Table 10. Diagnostic horizons and features, and classification of the studied soils of Magadu and Uyole Sites, Tanzania.

\begin{tabular}{llllll}
\hline Pedon No & $\begin{array}{l}\text { Diagnostic } \\
\text { horizon }\end{array}$ & $\begin{array}{l}\text { Reference Soil Group } \\
\text { (RSG) - TIER1 }\end{array}$ & $\begin{array}{l}\text { Principal } \\
\text { Qualifiers }\end{array}$ & $\begin{array}{l}\text { Supplementary } \\
\text { Qualifiers }\end{array}$ & WRB soil name - TIER 2 \\
\hline SUARAT-P1 & $\begin{array}{l}\text { Ochric horizon; } \\
\text { Argic horizon }\end{array}$ & Lixisols & Haplic & $\begin{array}{l}\text { Clayic, Cutanic, } \\
\text { Ochric, Profondic } \\
\text { Loamic, Colluvic, } \\
\text { Humic, }\end{array}$ & $\begin{array}{l}\text { Haplic Lixisols (Clayic, Cutanic, } \\
\text { Ochric, Profondic) } \\
\text { Eutric Andic Cambisols (Loamic, } \\
\text { Colluvic, Humic) }\end{array}$ \\
\hline
\end{tabular}

\section{Conclusions and Recommendations}

The SUARAT-P1 pedon is a very deep, acidic, clayey soil classified in the USDA Taxonomy as an Ultisol. The silt/clay ratio and $\mathrm{CEC}_{\text {clay }}$ has indicated that the soil is highly weathered. Its bulk density (BD) of less than $1.6 \mathrm{~g} \mathrm{~cm}^{-3}$ would favour good root penetration and water movement. The soil has been rated as low in organic matter, total nitrogen, and available phosphorus. The cation exchange capacity (CEC), electrical conductivity (EC), and basic nutrient balance are rated only as fair and favorable; soil is neither sodic nor saline. Generally the soil has limited fertility and needs significant management efforts to sustain agriculture and other land uses. Examples of management measures may include but not limited to supplementing with liming materials (to favorable $\mathrm{pH}$ levels and therefore alleviate $\mathrm{Al}$ and / or Fe toxicity) and soil reconstitution through addition of crop residues, manure, fertilizers ( $\mathrm{N}$ and $\mathrm{P})$. Crop rotations and intercropping with leguminous edible and cover crops may add significant amount of organic matter thereby improving the soil fertility.

Meanwhile, the UYOLE-P1 pedon is also a very deep soil but with slightly acidic to neutral reaction and dominantly loamy textural class. The pedon has been classified in USDA Taxonomy as a Cambisol. It is genetically a young soil as indicated by relatively high silt/clay ratios. It has quite favorable bulk density (BD) throughout its profile depth offering easy root penetration and water movement. With the medium rated $\mathrm{OM}$ and $\mathbf{N}$ (Low), $\mathrm{P}$ (Medium), and $\mathrm{K}$ (very high), observed in this study, together with its medium to high CEC and BS, the soil is likely to offer moderately favorable soil conditions for crop production. There is possibility of nutrient imbalance in this pedon which is likely to limit plant uptake of either $\mathrm{Mg}$ and or $\mathrm{K}$ due to unfavorable $\mathrm{Mg} / \mathrm{K}$ ratios 
and $\mathrm{Ca}$ /TEB values. Thus, efforts should also be invested in soil management through good management practices (GMP) to assure sustainable use of the soil resource for crop production and other land uses which may include residue incorporation and mulching amendment, use of organic manure, crop rotation and intercropping.

\section{References}

[1] Lufega, S. M. and Msanya, B. M. (2017). Pedological characterization and soil classification of selected soil units of Morogoro District, Tanzania. International Journal of Plant and Soil Science. 16 (1): 1-12.

[2] Msanya, B. M., Otsuka, H., Araki, S. and Fujitake, N. (2007). Characterization of volcanic ash soils in southwestern Tanzania Morphology, physicochemical properties, and classification. African Study Monographs. 34: 39-55.

[3] Kalala, A. M., Msanya, B. M., Nyambilila, A. and Semoka, J. M. R. (2017). Pedological characterization of some typical alluvial soils of Kilombero District, Tanzania. American Journal of Agriculture and Forestry, vol. 5, no. 1, pp. 1-11.

[4] Juilleret, J., Dondeyne, S., Vancampenhout, K., Deckers, J. and Hissler, C. (2016). Mind the gap: A classification system for integrating the subsolum into soil surveys. Geoderma, vol. 264, pp. 332-339.

[5] Moustakas, N. K. and Georgoulias, F. (2005). Soils developed on volcanic materials in the island of Thera, Greece, Geoderma, vol. 129 , pp. 125-138.

[6] Tenga, J. J., Msanya, B. M., Semoka, J. M., Semu, E. and Mwango, S. B. (2018). Pedological Characterization and Classification of Some Typical Soils in Three Agro-Ecological Settings of South-Eastern Tanzania", International Journal of Scientific and Engineering Research, vol. 9, no. 2, pp. 692-702.

[7] Shelukindo, H. B., Msanya, B. M., Semu, E., Mwango, S. B., Singh, B. R., and Munishi, P. (2014). Characterization of some typical soils of the miombo woodland ecosystem of Kitonga forest reserve, Iringa, Tanzania: Physico-chemical properties and classification. Journal of Agricultural Science and Technology, vol. 4, pp. 224-234.

[8] Msanya, B. M., Munishi, J. A., Amuri, N., Semu, E., Mhoro, L. and Malley, Z. (2016). Morphology, genesis, physico-chemical properties, classification and potential of soils derived from volcanic parent materials in selected Districts of Mbeya Region, Tanzania, International Journal of Plant and Soil Science, vol. 10, no. 4, pp. 1-19.

[9] Abitew, M. and Kebebew, S. (2016). Soil Fertility Status of Some Soil Orders and NuMaSS Fertilizer Recommendation at Bench-Maji Zone, South West, Ethiopia. Canadian Journal of Agriculture and Crops, vol. 1, no. 2, pp. 70-82.

[10] National Bureau of Statistics (NBS). (2017). Annual Agricultural Sample Survey (AASS) 2016-2017' https://www.nbs.go.tz/index.php/en/census-surveys/agricultur e-statistics/57-2016-17-annual-agriculture-sample-survey-crop -and-livestock-final-report, pp. 181.

[11] Soil Survey Staff. (2014). “Keys to Soil Taxonomy”, United States Department of Agriculture, 12th ed., Natural Resource Conservation Service, Washington, DC.
[12] IUSS Working Group WRB. (2015). World Reference Base for Soil Resources 2014, update 2015. International Soil Classification System for Naming Soils and Creating Legends for Soil Maps. World Soil Resources Reports No. 106. FAO, Rome.

[13] Ojoyi, M. M., Antwi-Agyei P., Mutanga O., Odindi J. and Abdel-Rahman E. M. (2015). An analysis of ecosystem vulnerability and management interventions in the Morogoro region landscapes, Tanzania. Tropical Conservation Science, vol. 8 , no. 3 , pp. $662-680$.

[14] National Bureau of statistics (NBS). (2018). Tanzania in figures. https://www.nbs.go.tz/index.php/en/tanzania-in-figures/422-ta nzania-in-figures-2018, pp. 112, 2019.

[15] FAO, (2006). Guidelines for Soil Description. 4th Edn. Food and Agriculture Organization of the United Nations, Rome. pp. 110 .

[16] Munsell Color Company. (1992). Munsell Soil Color Charts. Baltimore, Maryland. Lincoln, NE.

[17] Okalebo, J. R., Gathua, K. W. and Woomer, P. L. (2002) Laboratory methods of soil and plant analysis: A working manual" second edition. Sacred Africa, Nairobi, pp. 128.

[18] Nelson, D. W. and Sommers, L. E. (1982). Total organic carbon. In: L. A. Page, R. H. Miller, and D. R. Keeney (Eds.) Methods of soil analysis, Part 2 (2nd Ed.) Agronomy Monograph No. 9. American Society of Agronomy and Soil Science Society of America, Madison, WI. pp. 539-579.

[19] Bremner, J. R and Yeomans, J. C. (1998). Laboratory techniques. In: J. R Wilson (Ed) Advance in nitrogen cycling in agriculture ecosystem C. A. B Int. Willing, England.

[20] Moberg, J. (2001). Soil and Plant Analysis Manual. (Revised Edition). The Royal Veterinary and Agricultural University Chemistry Department, Copenhagen, Denmark. Pp. 133.

[21] Bray, R. H., Kurtz, L. T. (1945). Determination of total, organic, and available forms of phosphorus in soils. Soil Science, vol. 59 , pp. $39-45$

[22] Olsen, S. R. and Sommers, L. E. (1982). Phosphorus. In A. L. Page, et al (Eds.), Methods of Soil Analysis, 2nd ed. Part 2. Madison, WI: Agronomy No. 9. American Society of Agronomy, pp. 403-430.

[23] Watanabe F. S. and Olsen, S. R. (1965). Test of an ascorbic acid method for determining phosphorus in Central Illinois, Midwest Friends of the Pleistocene 26th Field Conf., Campaign, IL, Illinois Geological Survey Guidebook 13, pp. 129-134.

[24] National Soil Service (NSS). (1990). Laboratory procedures for routine analysis. 3rd edition, Agricultural Research Institute, Mlingano Tanga, Tanzania. pp. 212.

[25] Thomas, G. W. (1988). Exchangeable cations. In: A. I Page (Ed). Methods of soil analysis, part 2. Chemical and microbiological properties 2nd edition.

[26] Chapman, H. D. (1965). Cation Exchange Capacity, In: Methods of Soil Analysis. Part 1, 1st edition, Agronomy Monograph no. 6, (Edited by C. A. Black), American Society of Agronomy, Madison, Wisconsin, vol. 9, pp. 891- 901.

[27] Anderson, J. M., and Ingram, J. S. (1993). A handbook of methods. CAB International, Wallingford, Oxfordshire, pp. 221. 
[28] Baize, D. (1993). Soil science analysis. A guide to correct use. John Wiley and Sons Ltd. West Sussex. pp. 192.

[29] Lowery, B. and Morrison, J. E. (2002). Soil penetrometers and penetrability. In: Methods of Soil Analysis Part 4, Physical Methods (Eds JH Dane, GC Topp) Soil Science Society of America: Madison, WI, USA, pp. 363-388.

[30] Hazelton, P. and Murphy, B. "Interpreting soil test results: What do all the numbers mean?", CSIRO publishing, 2016

[31] Massawe, I. H., Msanya B. M. and Rwehumbiza, F. B. (2017). Pedological characterization and fertility evaluation of paddy soils of Mvumi village, Kilosa district, Tanzania, International Journal of Current Research in Biosciences and Plant Biology. vol. 4, no. 4, pp. 49-60.

[32] Neswati, R., Lopulisa, C. and Basir, A. (2019). Characteristics and Classification of Soil Formed from Banda Recent Volcanic Ash on Various Topographic Positions. In IOP Conference Series. Earth and Environmental Science. vol. 280, no. 1, p. 012017, IOP Publishing.

[33] Peverill, K. I., Sparrow, L. A. and Reuter, D. J. (Eds.). (1999). Soil analysis: an interpretation manual. CSIRO publishing: Melbourne.

[34] Brady, N. C. and Weil, R. R. (2008). The Nature and Properties of Soils. 12th edition. Prentice-Hall, Inc., Upper Saddle River, NJ, USA. pp. 881.

[35] Mukungurutse, C. S., Nyapwere, N., Manyanga, A. M. and Mhaka L. (2018). Pedological characterization and classification of typical soils of Lupane District, Zimbabwe. International Journal of Plant and Soil Science. vol. 22, no. 3, pp. 1-12.

[36] Shehu, B. M., Jibrin J. M. and Samndi A. M. (2015). Fertility Status of Selected Soils in the Sudan Savanna Biome of Northern Nigeria. International Journal of Soil Science. vol. 10, no. 2, pp. 74-83.

[37] Costantini, E. A., Angelone, M. and Damiani, D. (2002). Physical, geochemical and mineralogical indicators of aging in Quaternary soils of Central Italy. In: 17th World Congress of Soil Science, Transactions: International Union of Soil Sciences. vol. 599, pp. 1-9.

[38] Ribeiro, L. (1976). Introducao ao estudo da mineralogia dos solos de Ibitiara, BA, in Ana' is do de'cimo quinto congresso Sociedade Brasileiro de Cie^ncia do solo". ociedade Brasileira de Ciencia do Solo, Campinas, SP, Brazil, pp. 423-427.

[39] Sharu, M. B., Yakubu, M., Noma, S. S. and Tsafe, A. I. (2013). Characterization and classification of soils on agricultural landscapein Dingyadi District, Sokoto State, Nigeria. Nigerian Journal of Basic and Applied Sciences. vol. 21, no. 2, pp. 137-147.

[40] Landon, J. R. (2014). Booker Tropical Soil Manual: A Handbook for Soil Survey and Agricultural Land Evaluation in the Tropics and Subtropics. In: 2000 Symposium: Sugarcane: Research towards Efficient and Sustainable Production, Routledge, London, pp. 237-240.

[41] Arshad, M. A, Lowery, B, Grossman, B. (1996). Physical tests for monitoring soil quality. In Methods for Assessing Soil Quality; Doran, J. W., Jones, A. J., Eds, Soil Science Society of America: Madison, WI, USA.

[42] Scrimgeour, C. (2008). Soil Sampling and Methods of Analysis. Edited by MR Carter and EG Gregorich. Boca Raton, Fl, USA:
CRC Press (2008), pp. 1224, £ 85.00. ISBN-13: 978-0-8593-3586-0. Experimental agriculture. vol. 44, no. 3, pp. $437-437$.

[43] Msanya, B. M., Kimaro, D. N., Kileo, E. P., Kimbi, G. G. and Munisi, A. I. M. (2001). Land Resources Inventory and Suitability Assessment for the Production of the Major Crops in the Eastern Part of Morogoro Rural District, Tanzania. Soils and Land Resources of Morogoro Rural and Urban Districts, vol. 3. Department of Soil Science, Faculty of Agriculture, Sokoine University of Agriculture, Morogoro, Tanzania. Pp. 69.

[44] Ricardo. M. M. and Yost, R. (2006). A survey of soil fertility status of four agroecological zones of Mozambique. Soil science. vol. 171, no. 11, pp. 902-914.

[45] Mtama, J. G., Burras, C. L. and Msanya, B. M. (2018). Pedotransfer functions for cation exchange capacity, available water holding capacity and soil organic carbon for representative soils of southern highland zone of Tanzania. International Journal of Agriculture and Biological Sciences. vol. 2 , no. 10 , pp. 26-42.

[46] Nicolardot, B., Recous, S. and Mary, B. (2001). Simulation of $\mathrm{C}$ and $\mathrm{N}$ mineralisation during crop residue decomposition: a simple dynamic model based on the $\mathrm{C}: \mathrm{N}$ ratio of the residue. Plant and Soil. vol. 228, no. 1, pp. 83-103.

[47] Mtama, J. G., Msanya, B. M. and Burras, C. L. (2018). Pedology at four representative sites of Southern Highland Zone of Tanzania. American Journal of Agriculture and Forestry. vol. 6, no. 5, pp. 111-121.

[48] Kebeney, S. J., Msanya, B. M., Ng'etich, W. K., Semoka, J. M. R., Serrem, C. K. (2015). Pedological characterization of some typical soils of Busia County, Western Kenya: Soil morphology, physico-chemical properties, classification and fertility trends. International Journal of Plant and Soil Science. vol. 4, pp. 29-44.

[49] Msanya, B. M., Mwasyika, T. A., Amuri, N., Semu, E. and Mhoro, L. (2018). Pedological characterization of typical soils of Dodoma Capital City District, Tanzania: soil morphology, physico-chemical properties, classification and soil fertility trends. Annals of Advanced Agricultural Sciences, vol. 2, no. 4, pp. 59-73.

[50] Conklin, A. R. (2013). Introduction to soil chemistry: Analysis and instrumentation. John Wiley and Sons. pp. 376.

[51] Ma, C. (1996). The ultra -structure of kaolin. Ph.D. thesis, Australian National University, Canberra, Australia.

[52] Ma, C., Richard, A. and Eggleton, A. (1999). Cation exchange capacity of kaolinite. Clays and Clay Mineral. vol. 47, pp. 174 180.

[53] Miranda-Trevino, J. C. and Coles, C. A. (2003). Kaolinite properties, structure and influence of metal retention on $\mathrm{pH}$. Applied Clay Science. vol. 23, pp. 133-139.

[54] Macedo, J. and Bryant, R. B. (1987). Morphology, mineralogy, and genesis of a hydrosequence of Oxisols in Brazil. Soil Science Society of American Journal. vol. 51, pp. 690-698.

[55] Laekemariam, F., Kibret, K., and Shiferaw, H. (2018). Potassium (K)-to-magnesium $(\mathrm{Mg})$ ratio, its spatial variability and implications to potential $\mathrm{Mg}$-induced $\mathrm{K}$ deficiency in Nitisols of Southern Ethiopia. Agriculture and Food Security. vol. 7, no. 1, pp. 1-10. 
[56] Hailu, H., Mamo, T., Keskinen, R., Karltun, E., Gebrekidan, H. and Bekele, T. (2015). Soil fertility status and wheat nutrient content in Vertisol cropping systems of central highlands of Ethiopia. Agriculture and Food Security. vol. 4, no. 1, 1-10.

[57] Loide, V. (2004). About the effect of the contents and ratios of soil's available calcium, potassium and magnesium in liming of acid soils. Agronomy research. vol. 2 no. 1, pp. 71-82.

[58] Fageria, N. K., Baligar, V. C. and Clark, R. B. (2002). Micronutrients in crop production. Advances in agronomy. vol. 77, pp. 185-268.

[59] Sillanpää, M. (1982). Micronutrients and the nutrient status of soils: a global study (Vol. 48). Food and Agriculture Organization.

[60] Merumba, S. M., Msanya, B. M., Semu, E., Semoka. J. M. (2020). Pedological Characterization and Suitability Assessment for Cassava Production in Bukoba, Missenyi and Biharamulo Districts, Tanzania. American Journal of Agriculture and Forestry. vol. 8, no. 4, pp. 144-166.
[61] Gama-Castro, J. E., Solleiro-Rebolledo, E. and Vallejo-Gomez E. (2000). Weathered pumice influence on selected alluvial soil properties in west Nayarit, Mexico. Soil and Tillage Research, vol. 55 , pp. 143-165.

[62] Baba M, Hennie FW, Soehady E, Sanudin T. (2008). Geochemical characterization of volcanic soils from Tawau, Sabah. Bulletin of the Geological Society of Malaysia. vol. 54, pp. 33-36.

[63] Ruxton, B. P. (1968). Measures of the degree of chemical weathering of rocks. The Journal of Geology. vol. 76, no. 5, pp. 518-527.

[64] Uwingabire, S., Msanya, B. M., Mtakwa, P. W., Uwitonze, P. and Sirikare, S. N. (2016). Pedological characterization of soils developed on gneissic - Granites in the Congo Nile watershed divide and central plateau zones, Rwanda. International Journal of Current Research. vol. 8, no. 9, pp. 39489-39501.

[65] Tan, K. H. and Troth P. S. (1982). Silica-sesquioxide ratios as aids in characterization of some temperate region and tropical soil clays. Soil Science Society of American Journal. vol. 46, pp. 1109-1114. 